\title{
Karşılaştırmalı Hukuk Araştırmalarında Yöntem
}

\author{
Methodology of Comparative Legal Research
}

\author{
Çisil Durgun Arslan
}

\section{öz}

Karşılaştırmalı hukuk, esas itibariyle yabancı bir hukuka ilişkin bilgi edinilmesi, iç hukuk sisteminde gerekli görülen düzenlemelerin örnek alınacak hukuk modeli çerçevesinde gerçekleştirilebilmesi ve ihtiyaç duyulan alanlarda hukukun yeknesaklaştırılması amacıyla ortaya çıkan ve kendine özgü yöntemi olan bir hukuk disiplinidir. Ne var ki, söz konusu alanda çalışmak isteyen araştırmacılar çoğu zaman hangi yöntem ya da yöntemler çerçevesinde çalışmalarını gerçekleştirmeleri gerektiği hususunda tereddüt hissedebilirler. Bu doğrultuda, her türlü karşılaştırmalı hukuk araştırması bakımından en verimli sonuçlara ulaşmamızı sağlayabilecek tek bir yöntem önerisinde bulunulamaz. Nitekim, bu makalede esas itibariyle çalışmanın konusu ve amacı doğrultusunda uygulanabilecek olan yöntemlerin farklılık gösterebileceği anlatılmaya çalışılacaktır. Bilim insanları tarafından gerçekleştirilen akademik çalışmalar, yasa koyucunun üzerinde çalıștı̆̆ kanun metinleri ve hâkimler tarafından tesis edilen yargı kararları açısından büyük önem arz eden araştırma faaliyetlerinde; farklı yöntemlerin birbirini tamamlayıcı mahiyette bir arada uygulanabileceği ve söz konusu yöntemlerin birbirlerini dışlayan bir yapıda bulunmadıkları özellikle belirtilmeye çalışılacaktır. Bu makalede, karşılaştırmalı hukuk araştırması yapılırken başvurulabilecek yöntemler, esas itibariyle bilim insanları tarafından gerçekleştirilen araştırmalardaki ihtiyaçlar doğrultusunda tespit edilmeye çalışılmıştır.

Anahtar Kelimeler: Karşılaştırmalı hukuk, Hukuk metodolojisi, Hukukta yöntem, İşlevsel denklik yöntemi, Yabancı hukuk.

\section{ABSTRACT}

Comparative law is an independent legal discipline which mainly focuses on the purpose of to obtain knowledge regarding the foreign law, to discover the model act if it is necessary which guides the development of domestic law and to maintain uniformity if it is required. However, researchers can easily hesitate when embarking on comparative legal research regarding the kind of methodology to be followed, nor even on the methodologies that could be followed. Accordingly, we need not a fixed methodological road map, which could fruitfully be applied in all comparative research. Basically, the aim of this article is to determine the different methods that could usefully be applied according to the subject and the purpose of the research. Comparative law is indispensable for all the research done by the academics, by legislators who works for legal texts and court decisions ruled by the judges. Therefore, different methods may be combined, as they are complementary and not mutually exclusive. This article focuses on the specific demand regarding the application of different methods especially by the scholars.

Keywords: Comparative law, Legal methodology, Methodology in law, Functional equivalence method, Foreign law.

Ar. Gör. Dr., Marmara Üniversitesi Hukuk Fakültesi Medeni Hukuk Anabilim Dalı

Sorumlu Yazar/Correspondence Author: Çisil Durgun Arslan

E-posta/E-mail: cisil.durgun@marmara.edu.tr

Geliş Tarihi/Received: $\quad$ 19.08.2021

Kabul Tarihi/Accepted:

21.08.2021 


\section{GíRiş}

1900 yılında gerçekleşen Paris Dünya Fuarı (Paris World Exhibition), dünyanın farklı coğrafyalarından gelen katılımcıların sadece ülkelerindeki teknolojik gelişmeleri tanıtma olanağına sahip oldukları bir etkinlik olarak değil; aynı zamanda Fransız düşünürleri Édouard Lambert ve Raymond Saleilles'in katkıları ile Birinci Uluslararası Mukayeseli Hukuk Konferansına (First International Congress of Comparative Law) öncülük etmesi ile de özdeşleşmiştir ${ }^{1}$. Fuara hâkim olan güven ortamında düşünürlerin barışçıl bir yaklaşımla dünyadaki gelişmeleri anlamaya ve öğrenmeye duydukları heves, kuşkusuz hukukçuları da büyük ölçüde etkilemiştir. Karşılaştırmalı hukukun ${ }^{2}$ kendine özgü yöntemi olan yeni bir hukuk disiplini ${ }^{3}$ olarak görülmesini sağlayan Lambert ve Saleilles önderliğindeki konferansta, karşılaştırmalı hukuk çerçevesinde herkesin üzerinde uzlaşabileceği ortak bir hukuk yaratmanın (common law of mankind) önemi fikri ortaya çıkmıştır. Söz konusu ortak iradenin kısa bir zaman dilimi içerisinde gerçekleşmesinin mümkün olmayacağı üzerinde hemfikir olunmasına rağmen; böylesi bir iradeye duyulan ihtiyaç üzerinde ortak bir kanaate varılmış olması, karşılaştırmalı hukuk alanında atılmış resmi anlamdaki ilk adımı oluşturmaktadır.

Bu yaklaşım, kültürel ve sosyal gelişimini benzer şekilde devam ettiren toplumlar arasında; politik ya da ahlaki sebeplerle, sosyal gereksinimlerle açıklanamayan; tarihsel tesadüfler yahut geçici nedenler sonucunda ortaya çıkmış hukuk uygulamalarındaki rastlantısal farklılıkların, karşılaştırmalı hukuk doğrultusunda giderilebileceği yönündeki kanaati güçlendirmiştir. Dolayısıyla, 20. yüzyıldan itibaren ekonomik ve teknolojik gelişmelerin devletler arası ilişkilerde yol açtığı değişim, karşılaştırmalı hukuk ${ }^{4}$ bakımından; uluslar arasındaki soyutlanmaların giderek zayıflamış olması şeklinde etkisini göstermiştir. Karşılaştırmalı hukuk araştırmaları sonucunda birbirleri ile yoğun bir iletişim içerisinde olan farklı hukuk sistemlerinin bakış açıları arasındaki benzerlikler daha çok hissedilmeye,

1 Konrad Zweigert and Hein Kötz, An Introduction to Comparative Law (Tony Weir tr, 3rd edn, Oxford University Press 1998) 2 vd.; Bénédicte Fauvarque-Cosson, 'Development of Comparative Law in France' in Mathias Reimann ve Reinhard Zimmermann (eds), The Oxford Handbook of Comparative Law (Oxford University Press 2006) 39, 42 vd.

2 Karşılaştırmalı hukukun (Karşılaştırmalı hukukun tarihsel gelişimi ile ilgili detaylı bilgi için bkz. Esin Örücü, 'Karşılaştırmalı Hukukta Eski ve Yeni' (Nurcan Yılmaz Özel tr, İdare Hukuku ve İlimleri Dergisi, 18 (1) 2019) 79,83 vd. (Örücü, Eski ve Yeni); Zweigert and Kötz (n 1) 48 vd.; Charles Donahue, 'Comparative Law Before the Code Napoléon' in Mathias Reimann ve Reinhard Zimmermann (eds), The Oxford Handbook of Comparative Law, (Oxford University Press 2006) 4, 4 vd.; Jürgen Basedow, 'Comparative Law and Its Clients', (2014) 62 (4) The American Journal of Comparative Law (2014) 821. Bu makalenin Türkçe çevirisi için bkz. Jürgen Basedow, 'Karşılaştırmalı Hukuk ve Kullanıcıları’ (Gökçe Kurtulan tr) (2016) LXXIV (2) İÜHFM 879, 887) tanımı, amaçları ve yöntemleri ilk defa bu konferansta tartıșılmıștır. Bkz. Zweigert and Kötz, (n 1) 3. Karşılaştırmalı hukukun hukuk metodolojisindeki fonksiyonları ile ilgili bilgi için bkz. O. Gökhan Antalya, Hukuk Metodolojisi, (Seçkin 2021) para. 3398 vd.

3 Karşılaştırmalı hukuk, kendine özgü mevzuatı olan bir hukuk alanı değildir. Karşılaştırmalı hukuk, dünya üzerinde ne kadar farklı hukuk sistemi varsa, tüm bu sistemler arasındaki karşılaştırma faaliyetinin nasıl, hangi amaç doğrultusunda ve ne için gerçekleștirileceğini temsil eden bir hukuk disiplinidir. Karşılaştırmalı hukuku niteliği itibariyle sadece bir metod olarak kabul eden veya bağımsız bir hukuk disiplini olarak gören ya da karşılaştırmalı hukukun birden çok amaç ve işlevi olduğu savunan yahut karşılaştırmalı hukukun evrensel olduğunu ileri süren yazarların görüşleri hakkında ayrıntılı bir değerlendirme için bkz. Arzu Oğuz, 'Hukukun Bağımsız Bir Alanı Olarak Karşılaştırmalı Hukukun Konusu ve Metodu', (2002) 22 (2) Milletlerarası Hukuk ve Milletlerarası Özel Hukuk Bülteni 451, 465 vd.

4 20. yüzyıldan günümüze kadar sürekli değişerek gelişen karşılaştırmalı hukuk anlayışında 21. yüzyılda benimsenen tavır ve tartışmalar, bir önceki yüz yıldan önemli ölçüde farklılaşsa da "karşılaştırmalı hukuk" kavramı günümüzde farklı çevrelerin üzerinde uzlaşabildiği bir kavram hâline gelmiştir. 
üzerinde mutlak bir anlaşmaya varıldığına inanılan ve değiştirilemez şekilde nitelendirilen yerleşik anlayışların ise çözülmeye başladığı görülmüştür ${ }^{5}$. Bu sayede, hukuk kurallarının biçim ve içerik bakımından birbiri ile benzer bir gelişim sergilediği dururumlar ile birbirinden derin bir şekilde ayrıştı̆̆g durumlarda dahi, özdeş bir adalet anlayışının temin edilebileceği yönündeki kanaat, farklı çevrelerde kabul edilmeye başlanmıştır ${ }^{6}$. Karşılaştırmalı hukuk araştırmaları, ortak bir hukuk anlayışı ile yalnızca uluslararası ticaretin gelişmesine, yatırım faaliyetlerinin dünya genelinde daha dengeli bir yapıya kavuşmasına ve bu sayede, insanların yaşam seviyelerinin yükselmesine olanak sağlamamaktadır. Tüm bu katkılarının yanında ayrıca, değişen ihtiyaçlar karşısında ülkelerin mevcut hukuk kurallarını yorum faaliyeti ile nasıl geliştirebilecekleri ya da gerekli görülmesi hâlinde, nasıl yeniden düzenleyebilecekleri konusunda da önemli bir kaynak niteliğindedir ${ }^{7}$.

Karşılaştırmalı hukuk araştırmalarının gelişimi ilk olarak, farklı hukuk sistemlerindeki kurallar ya da içtihatlardan yola çıkılarak ortak bir kural ve kavramlar bütününe ulaşılması yönünde olmuştur $^{8}$. Belirtmek gerekir ki, bu yaklaşımın esasında hukukun yeknesaklaştırılması amacı değil; farklı sistemlerin ortak temelinin bulunması hedeflenmiştir ${ }^{9}$. Nitekim, karşılaştırma faaliyetinin temelini de bu ilk aşama oluşturmaktadır. Karşılaştırmalı hukuk araştırmasının, birinci aşaması ile birlikte gelişmeye başlayan ikinci aşamasında ise, yabancı bir hukuk sisteminin anlaşılması amacını hedefleyen, bu doğrultuda da çoğu zaman söz konusu ulusun kültüründen istifade edilmesi gerekliliğini ortaya çıkaran karşılaştırma düzeyleri öne çıkmışıır ${ }^{10}$. Hukuk sisteminin ${ }^{11}$ bütününe odaklanan karşılaştırma düzeyi, "makro-karşılaştırma" olarak öğretide tanımlanmaktadır ${ }^{12}$. Karşılaştırmalı hukuk araştırmasının üçüncü aşamasında ise, belirli hukuki sorunların yabancı bir hukuk sisteminde nasıl çözümlendiği araştırılmaktadır. "Mikro-karşılaştırma" olarak nitelendirilen bu karşılaştırma düzeyi ile, belirli konulara ilişkin olarak farklı hukuk sistemlerinde üretilen çözümler gerçek anlamda karşılaştırılabilir bir hâle gelmiştir ${ }^{13}$. Mikro-karşılaştırma aşamasının tamamlanması ile, aslında söz konusu hukuk sistemi bahsi geçen hukuki sorun çerçevesinde tam anlamıyla değerlendirilmekte ve makro karşılaştırma ile mikro karşılaştırma aşamaları bütünleşmektedir ${ }^{14}$.

Somutlaştırmak gerekirse, Avrupa Birliği hukuku ile Avrupa Birliği üyesi devletlerin milli hukukları arasında gerçekleștirilecek olan karşılaştırma faaliyetinde ${ }^{15}$, her iki hukuk sisteminin

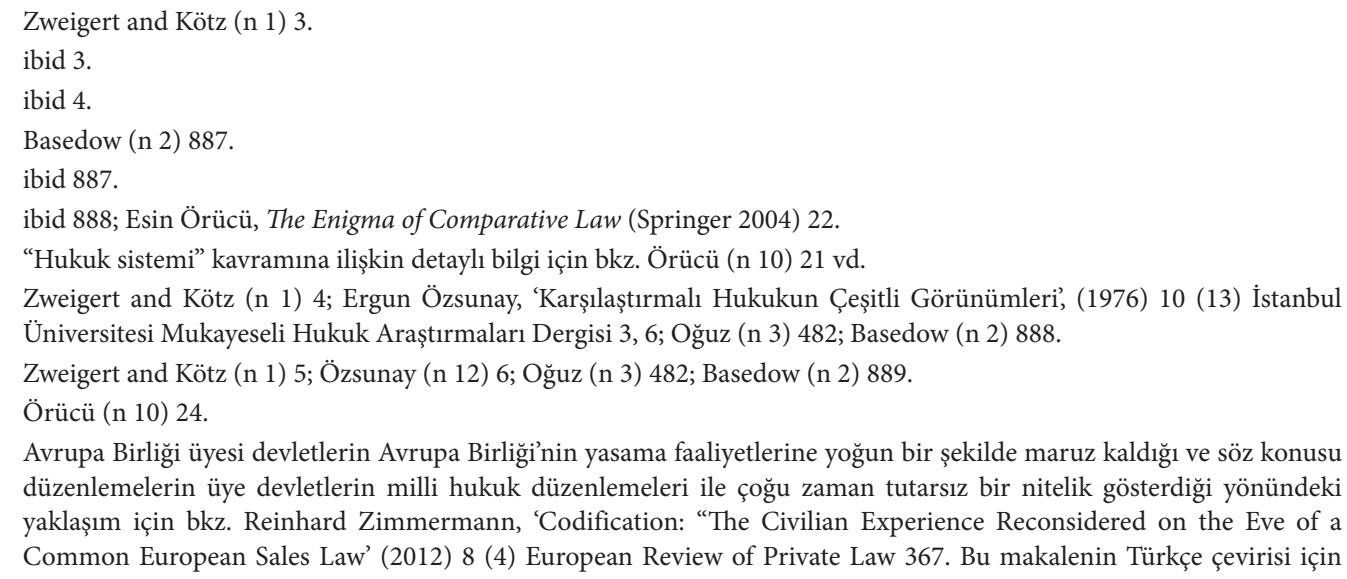
düzenlemelerin üye devletlerin milli hukuk düzenlemeleri ile çoğu zaman tutarsız bir nitelik gösterdiği yönündeki yaklaşım için bkz. Reinhard Zimmermann, 'Codification: "The Civilian Experience Reconsidered on the Eve of a Common European Sales Law’ (2012) 8 (4) European Review of Private Law 367. Bu makalenin Türkçe çevirisi için 
yapısal anlamdaki farklılıkları ve temel maksatları arasındaki başkalık, uygulanabilecek yöntemler ve karşılaştırma düzeyi üzerinde de büyük etkiye sahiptir. Örneğin, Avrupa Birliği hukukunun, piyasalar arasındaki entegrasyonu sağlamaya yönelik olarak ulusal sigorta piyasaları için getirmiş olduğu düzenlemeler ile Avrupa Birliği üyesi devletlerin ulusal sigorta sistemleri arasındaki farklılık, Avrupa Birliği hukukunun bu alanda bütünleyici bir etkiye sahip olmadığını göstermektedir. $\mathrm{Bu}$ durum, karşılaştırmaya konu edilen sistemler ve düzenlemeler arasındaki farklılığın, aşağıda ayrı ayrı ele alınacak olan hem işlevsel bakımdan denklik yöntemi hem de yapısal ve analitik yöntemler çerçevesinde yapılacak derinlemesine bir araştırma ile anlaşılabileceğini göstermektedir. Karşılaştırma düzeyi bakımından ise, her iki hukuk sisteminin de birbirine olan bağımlılığı, karşılaştırmalı hukuk araştırmacısının söz konusu sistemleri birbirinden ayrı ve bağımsız şekilde inceleyebilmesi önünde engel teşkil etmektedir. Dolayısıyla, araştırmacının mikro ve makro karşılaştırma aşamalarını bir bütün hâlinde tek bir aşama olarak düşünüp, değerlendirmelerini bu yaklaşım doğrultusunda gerçekleştirmesi gerekmektedir. Bu durum, Avrupa Birliğinde karar verme sürecinde etkin rol oynayan kurumlar ile Avrupa Birliği üyesi devletlerdeki karar vermeye yetkili organlar arasındaki farklılıkları da hem işlevsel denklik yöntemi açısından karşılaştırmamız gerektiğini hem de ilgili organların kendi sistemleri içerisindeki yetkinliğini eksiksiz şekilde tespit edip, aralarında benzer ya da farklı bir yapının bulunup bulunmadığını doğru biçimde belirlememizi gerektirmektedir. Ayrıca tüm bu süreci temel bir çerçevede ele alabilmek ve farklı organlar arasındaki ilişkiyi saptayabilmek için, yapısal yöntemden ve bütün mekanizmanın geçmişten günümüze kadar gösterdiği değişimi anlayabilmek için de tarihsel yöntemden istifade etmek lâzımdır.

Görüldüğü üzere, karşılaştırmalı hukuk araştırmalarında uygulanabilecek yöntem ${ }^{16}$ ya da yöntemler ile karşılaştırma düzeyleri hem birbiriyle iç içe hem de birbirinden ayrı biçimde değerlendirilmesi gereken hususlardır. Burada gerek yöntem gerekse de karşılaştırma düzeyinin seçimi, gerçekleştirilmesi hedeflenen araştırmanın konusuna bağlı olarak değişiklik gösterebilecektir. Çalışmamızda ise, karşılaştırmalı hukuk araştırmalarında uygulanabilecek yöntemlerin neler olduğu, söz konusu yöntemlere ilişkin öğretide getirilen temel nitelikteki eleștiriler ile birlikte ele alınmaya çalışılacaktır. Her ne kadar yasa koyucu ve hâkimler tarafından gerçekleştirilen karşılaştırmalı hukuk araştırmaları da öğreti açısından oldukça eğitici olsa da, kanaatimizce söz konusu alanda en büyük katkıyı sağlayacak olan bilim insanlarıdır. Bu nedenle de çalışmamızda, tüm bu yöntem çoğulluğu içerisinde esas itibariyle bilim insanları tarafından gerçekleștirilen karşılaştırmalı hukuk araştırmalarında hangi yöntem ya da yöntemlerin benimsenmesi durumunda en verimli sonuçlara ulaşılabileceği anlatılmaya çalışılacaktır.

bkz. Reinhard Zimmermann, 'Kodifikasyon: Avrupa Ortak Satım Hukuku Arifesinde Kita Avrupası Deneyimlerinin Değerlendirilmesi’ (Ece Baş Süzel ve Meliha Sermin Paksoy trs) (2015) LXXIII (2) IÜHFM 409, 424 vd.

16 İzlenecek yöntemin sosyal, kültürel ve politik arka planı ve genel olarak hukukta yöntem tartışmasına ilişkin ayrıntılı bir değerlendirme için bkz. Rona Serozan, 'Hukukta Yöntem’ (2013) 8 Yaşar Üniversitesi E-Dergisi (Prof. Dr. Aydın Zevklilere Armağanı), 2423, 2423 vd. 


\section{KARŞILAŞTIRMALI HUKUK ARAŞTIRMALARINDA UYGULANABILECEK YÖNTEMLER}

Karşılaştırmalı hukuk araştırmasını gerçekleştiren bilim insanlarının, çoğu zaman belirli bir yöntem çerçevesinde araştırmalarını temellendirmemeleri, öğretide sıklıkla eleştirilmektedir. Bu duruma ilişkin olarak Van Hoecke, karşılaştırmalı hukukçuların dünyanın farklı coğrafyalarına seyahat eden bir gezgin gibi davrandıklarını ve karşılaştıkları benzerlik ve farklılıkları yetiştikleri coğrafya ile kıyaslayarak yabancı hukuk sistemleri ve dolaylı olarak yabancı kültürler hakkında bilgi sahibi olabilecekleri yönündeki inanışlarını cüretkâr bulduğunu belirtmektedir ${ }^{17}$. Gerçekleștirilen seyahat sonrasında ilgili coğrafyaya ilişkin izlenimlerimizi, gördüğümüz tarihi yapıları çoğu zaman sosyal çevremizle paylaşırız. Ne var ki, söz konusu coğrafyanın kültürü, sosyolojik yapısı ya da tarihi eserleri ancak konusunda uzman bir kişi tarafından bilimsel nitelikte bir değerlendirmeye konu edilebilir ${ }^{18}$. Günümüzde hukuk eğitiminin ağırlıklı olarak ulusal kurallar üzerine kurulu ${ }^{19}$ olduğu düşünüldüğünde; belirli bir hukuk sisteminin etkisi altında yetişmiş hukukçu bilim insanının, karşılaştırmalı bir bilimsel araştırma gerçekleştirmesinin; bir tarihçi, sosyolog, antropolog ya da siyaset bilimciye kıyasla daha zor olacağı söylenebilir.

Ayrıca, karşılaştırmalı hukuk araştırmasını gerçekleştiren hukukçuların ilgi alanlarının birbirinden önemli ölçüde farklılık arz etmesi de yapılan araştırmada benimsenecek yöntem açısından farklılık gösterebilir. Bazı hukukçular, bir hukuk sisteminin tamamıyla ilgilenmeyi tercih ederken; diğerleri, hukukun belirli bir alanı ile veya bir hukuki kurum üzerinden söz konusu karşılaştırmayı

17 Mark Van Hoecke, 'Methodology of Comparative Legal Research' (2015) Law and Method 1, 8.

18 ibid 8. Van Hoecke’nin verdiği örnek doğrultusunda aktarmaya çalıștığı yaklaşımına, bazı hususları ilave etmek istemekteyiz. Kanaatimizce de bir gezginin (karşılaştırmalı hukuk araştırmacısının) bir toplum ile olan teması ne kadar yoğun olursa, o toplumun ihtiyaçları, alışkanlıkları, sorunları çözme yöntemi hakkında daha çok bilgi sahibi olma fırsatı olur. Herhangi bir konuya ilişkin bir araştırma faaliyetini gerçekleştirmek üzere bir haftalığına yabancı bir ülkeye seyahat eden bir gezgin ile aynı araştırmayı ilgili toplumda bir yıllık bir süre içerisinde aşama aşama yapma olanağına sahip olan bir gezginin izlenimlerinin aynı yoğunlukta olma ihtimali oldukça zayıftır. Zira bir hafta geçirmeyi planladığınız bir seyahat süresince, karşılaşabileceğiz sorunlar ve söz konusu sorunları nasıl çözebileceğiniz doğrultusunda tercih edebileceğiniz yöntemlere ilişkin seçenekler; aynı toplumda aynı sorunla karşılaşan ve bir yıla yakın bir zaman geçirmiş bir gezginin seçeneklerine göre çok daha sınırlıdır. Kısa bir süre içerisinde gelişen ve hızlıca çözüm üretmemiz gereken ihtiyaçlarımızı giderirken, çoğu zaman en kolay ve hızlı sonuç alabileceğimiz yöntemi tercih etme eğiliminde oluruz. Hâlbuki, söz konusu sorunu çözebilmek bakımından bir zaman sınırlaması içinde olmadığımızda; en makul yöntemi bulabilmek açısından elimizdeki diğer seçenekleri de değerlendirme imkânına sahip oluruz. Aynı durum, karşılaşma ihtimalimizin olduğu sorunların çeşitliliği ve zorluğu açısından da geçerlidir. Örneğin, bir seyahat süresince rahatsızlanıp tedavi için bir hastaneye başvurma ihtiyacımızın ya da noter huzurunda düzenlenmiş resmi bir evrak tanziminine olan gereksinimimizin, bir yıl süre ile kalacağımız bir ülkede, bir hafta süreye kıyasla gerçekleşmesi daha çok ihtimal dahilindedir. Diğer yandan, bazı durumlarda sadece geçici bir süre için bir yerde bulunan kişinin, bulunduğu topluma yabancı olması hasebiyle, söz konusu toplumun içinde yaşayan bir kişinin sahip olmadığı bir bakış açısıyla sorunları tespit edebilme ya da çözümleyebilmesi de imkân dahilindedir.

19 Tarihçi Hukuk Bilimi Ekolü’nün, karşılaştırmalı hukuka gerekli itibarı göstermemiş olmasıı ve karşılaştırmalı hukuka, sadece yasa koyucuya yardımcı bir rol atfetmiş olması da dogmatik hukuk biliminin önemini perçinlemiştir. Bkz. Örücü, Eski ve Yeni (n 2) 82. Her ne kadar hukuk sistemlerinin etkileşimine ilişkin artan farkındalık, 19. yüzyılın başlarından itibaren farklı şekillerde kendini gösterse de karşılaştırmalı hukuk araştırmasına dayanan evrensel bir hukuk disiplinine 20. yüzyılın başlarına kadar ihtiyaç duyulmamıştır. Karşılaştırmalı hukuk araştırmalarının, sistematik bir yöntem doğrultusunda yürütülmesi gerekliliğine ilişkin inancın, günümüzdeki anlamına kavuşması ise, çok daha sonraki bir döneme isabet etmektedir. ibid 83. Karşılaştırmalı hukuk araştırmalarının hukuk eğitimine katkısına ilişkin bir değerlendirme için bkz. Basedow (n 2) 896. 
gerçekleştirebilirler ${ }^{20}$. Benzer bir şekilde bazı hukukçular; hukukun kültür, politika ya da diğer sosyo-ekonomik ölçütlerle olan etkileşimini de çalışmalarında esas alırken; diğerleri, sadece belirli bir hukuki kurumu ya da hukuk kuralının uygulamasını ele almayı tercih etmektedir ${ }^{21}$. Yine bazı hukukçuların amacı, farklı hukuk sistemleri arasındaki benzerliklerin tespit edilmesiyken; diğerleri, sadece mevcut farklılıklar üzerinden çalışmasını gerçekleştirmeyi tercih edebilir ${ }^{22}$. Son olarak karşılaştırmalı hukuk araştırması, sadece akademik amaçlarla ${ }^{23}$ gerçekleştirilebileceği gibi, yasa koyucu tarafından yürütülen yasama faaliyetine katkı sağlamak amacıyla ${ }^{24}$ ya da yeknesak hukuk kurallarının yaratılmasına yönelik bir yaklaşım doğrultusunda ${ }^{25}$ veya da yabancılık unsuru ihtiva eden durumlarda söz konusu yabancı hukukun doğru bir biçimde uygulanabilmesi amacıyla somut uyuşmazlığı değerlendiren hâkim tarafından da yapılabilir ${ }^{26}$.

Tüm bu ihtimallerden de anlaşılacağı üzere, karşılaştırmalı hukuk araştırmalarının yapılması ile hedeflenen amaç her durumda farklılık gösterebileceği gibi, bu amaç doğrultusunda benimsenecek yöntem ya da yöntemler ${ }^{27}$ de değişiklik gösterebilir ${ }^{28}$. Bir diğer ifadeyle, karşılaştırmalı hukuk araştırmalarına atfedilen amaçlar arasındaki söz konusu farklılık, araştırmada hedeflenen amacın ve araştırmaya konu olan soruna en uygun yöntemin seçilmesi gerekliliğine de dikkat çekmektedir ${ }^{29}$. Benimsenecek yöntemin doğru tespit edilmesi, çalışmada hedeflenen amacın gerçekleşmesi açısından büyük önem arz etmektedir. Bu doğrultuda, araştırma konusunun seçiminden bilimsel çalışma tamamlanıncaya kadar hangi yöntem ya da yöntemlerin izlenmesi gerekeceği, mümkün olduğunca çalışmanın başında belirlenmelidir ${ }^{30}$. Bu noktada her türlü hukuki soruna uygulanabilecek nitelikte değişmez bir formül önermek mümkün değildir ${ }^{31}$. Bu nedenle, tüm bu yöntem çoğulluğu içerisinde karşılaştırmalı hukuk araştırmasının nasıl yapılması gerektiğine ilişkin verilecek karar; hem araştırmanın amacına hem de araştırmaya konu olacak yabancı hukukun en doğru şekilde nasıl anlaşılabileceği sorusuna verilecek yanıt doğrultusunda şekillenecektir. Karşılaştırmalı hukuk araştırmalarında uygulanabilecek yöntemlere ilişkin herkes için kabul edilebilir ortak bir tasnif bulunmadığından; öğretide hem en çok kabul edilen hem de en çok eleştirilen temel yöntemlerden, aşağıda bahsedilecektir. Söz konusu yöntemler, karşılaştırmalı hukuk araştırmalarında taşıdığı

20 Jaakko Husa, 'Methodology of Comparative Law Today: From Paradoxes to Flexibility?' (2006) 58 (4) In: Revue internationale de droit comparé, 1095, 1097; Basedow (n 2) 892.

21 Basedow (n 2) 892.

22 Husa (n 20) 1097; Basedow (n 2 ) 892.

23 Basedow (n 2) 895 vd.

24 Detaylı bilgi için bkz. ibid $900 \mathrm{vd}$.

25 Detaylı bilgi için bkz. ibid 906 vd.

26 ibid 892.

27 Husa (n 20) 1098; Van Hoecke (n 17) 9. Bu durum, öğretide Martin Gebauer tarafından “yöntemsel çoğulculuk” olarak nitelendirilmiştir. Bkz. Martin Gebauer, 'Rechtsvergleichung' in Hanno Kobe and others (eds), Leitgedanken des Rechts, Paul Kirchhof zum 70. Geburtstag, Heidelberg (2013) 433 vd. (Basedow (n 2) 893 dpn. 43'den naklen).

28 Van Hoecke (n 17) 9; Basedow (n 2) 893.

29 Van Hoecke (n 17) 9; Oğuz (n 3) 488.

30 Oğuz (n 3) 488.

31 ibid 488. 
özellikler doğrultusunda adlandırılmış olup, her bir yöntem bir diğeri ile uyum içerisinde uygulanma özelliğini haizdir.

\section{A. IŞLEVSEL DENKLIK YÖNTEMi}

İşlevsel denklik yöntemi (functional equivalence method), belirli bir hukuki sorun için farklı hukuk sistemlerinde üretilen çözümlerin, işlevsel açıdan büyük ölçüde benzer olduğu şeklindeki bir varsayımdan hareket etmektedir ${ }^{32}$. Bu yaklaşımın temelinde, hangi hukuk sistemi benimsenirse benimsensin insanların karşılaştıkları sosyal sorunların ortak olduğu fikri hâkimdir ${ }^{33}$. Zira aynı gelişmişlik düzeyindeki hukuk düzenlerinde ${ }^{34}$, hukuki ilişkilerdeki benzer gereksinimler doğrultusunda üretilen çözümlere farklı yollardan ulaşılsa dahi, söz konusu çözümlerin pratik açıdan oldukça benzer olduğu düşünülmektedir ${ }^{35}$.

1971 yılında Zweigert ve Kötz tarafından ileri sürülen işlevsel denklik yöntemi ${ }^{36}$; bazı hukuk çevrelerinde, en verimli ve adeta inhisari nitelikte bir yöntem olarak kabul edilirken ${ }^{37}$; aksi görüşü benimseyenler ise, karşılaştırmalı hukuk alanındaki tüm olumsuzlukların, söz konusu yöntemden kaynaklandığını düşünmektedir ${ }^{38}$. Öğretide farklı açılardan yoğun şekilde tartışılan işlevsel denklik yöntemine ilişsin eleştirileri ${ }^{39}$, Michaels'in söz konusu yönteme ilişkin üç başlık altında sıraladığı

32 Zweigert and Kötz (n 1) 34. İşlevsel denklik yönteminin tanımı için bkz. Ralf Michaels, 'Two Paradigms of Jurisdiction', (2007) 27 Michigan Journal of International Law 1003, 1004 (Michaels, Paradigms); Ralf Michaels, 'The Functional Method of Comparative Law' in Mathias Reimann ve Reinhard Zimmermann (eds), The Oxford Handbook of Comparative Law, (Oxford University Press 2006) 369; Oğuz (n 3) 462.

33 Zweigert and Kötz (n 1) 34 vd.; Oğuz (n 3) 488 vd.; Örücü Eski ve Yeni (n 2) 84. İnsanların karşılaştığı sosyal sorunların benzer olduğu yönündeki yaklaşımın temelinde, hukukun birleştirilebilmesi amacının bulunduğu yönündeki görüş için bkz. Michaels (n 32) s. 376; Michaels Paradigms (n 32) 1005.

34 Karşılaştırmalı hukuk araştırmacılarının, gelişmişlik düzeyi birbirine yakın olan ülkelerdeki hukuki sorunları, karşılaştırma faaliyetine daha çok konu etmesi yönündeki alışkanlığın eleştirisi için bkz. Michaels (n 32 ) 368. Karşılaştırılacak hukuk düzenlerinin seçimine ilişkin ayrıntılı bir değerlendirme için bkz. Oğuz (n 3 ) 490 vd.

35 Zweigert and Kötz (n 1) 34 vd.; Michaels (n 32) 369; Oğuz (n 3) 488 vd.; Basedow (n 2) 889; Örücü Eski ve Yeni (n 2) 84 vd.; Van Hoecke (n 17) 9 vd. Toplumların karşılaştıkları sorunların benzer şekilde çözümlenmesinin temelinde; yasa koyucunun, mahkemelerin ve bilim insanlarının karşılaştıkları sorunların çözümüne ilişkin özellikle hukuk iktibası çalışmaları sırasında birbirlerinin sistemlerinden almış oldukları ilham olduğuna ilişkin bkz. Esin Örücü, 'Law As Transposition' (2002) 51(2) The International and Comparative Law Quarterly 205, 205 vd. (Örücü, Transposition).

36 İşlevsellik yönteminin karşılaştırmalı hukuk açısından temelini atan Zweigert ve Kötz'ün konuya ilişkin yaklaşımı şu şekilde özetlenebilir: Hukuki sorunlara ilişkin çözümlerin, mutlaka kanuni bir şekilde çözümlenmesi gerekmemekte, bazı durumlarda gelenek ve teamüller çerçevesinde de çözüm sağlanabilmektedir. Bu nedenle karşılaştırmalı bir hukuk araştırmacısı için en uygun olan yöntem, söz konusu hukuki soruna ilişkin normun tespitini doğru bir biçimde gerçekleştirdikten sonra, diğer hukuk sistemlerinde işlevsel açıdan ilgili norma denk gelen düzenlemeleri birbirleri ile karşılaştırmaktır. Bkz. Zweigert and Kötz (n 1) 34.

37 Oğuz (n 3) 462 vd., 486.

38 Michaels (n 32) 340.

39 İşlevsel denklik yöntemi çerçevesinde gerçekleştirildiği ileri sürülen karşılaştırmalı hukuk çalışmalarının, çoğu zaman söz konusu yönteme ilişkin yukarıda bahsedilen ve öğretide tarafından genel itibariyle kabul gören temel yaklaşımı yansıtamadığı anlaşılmaktadır. Bu doğrultuda öne çıkan pek çok çalışmada, araştırma konusu hukuki sorunun çözümüne ilişkin ele alınan mahkeme kararının ya da hukuk kuralının veya hukuki kurumun, sadece biçimsel bir yaklaşım doğrultusunda değerlendirildiği söylenebilir. (Samuel, öğretide konuya ilişkin bu yönde ileri sürülen eleştirilere çalışmasında detaylı bir şekilde yer vermektedir. Bkz. Geoffrey Samuel, An Introduction to Comparative Law Theory 
eleştirisi ile özetlemek mümkündür: "İşlevsel denklik yöntemi, üç bakımdan yanlışlı ihtiva etmektedir. Öncelikle, öğretide tek bir işlevsel denklik yöntemi değil, pek çok işlevsel denklik yöntemi bulunmaktadır. İkinci olarak, işlevsel açıdan denk olduğu ileri sürülen yöntemlerin tamamı işlevsel değildir. Son olarak, işlevsel denklik yöntemi çerçevesinde gerçekleştirildiği belirtilen bazı çalışmalarda, tanınabilir herhangi bir yöntemin takip edilmediği anlaşılmaktadır" ${ }^{40}$. Karşılaştırmalı hukukta işlevsel denklik yöntemi üzerinden gerçekleşen bu kutuplaşma sebebiyle, araştırmacının işlevsel denklik yöntemine ilişkin yaklaşımının; onun karşılaştırmalı hukuka ilişkin diğer pek çok sorunu nasıl çözümleyeceği hususunda da okuyucuya önemli ipuçları verdiği, öğretide kabul edilmektedir ${ }^{41}$.

Peki, işlevsel denklik yöntemi esasında hangi anlama gelmektedir? Bu yöntemin taraftarları, belli başlı unsurlar üzerinde uzlaşmaktadır ${ }^{42}$ : Öncelikle, işlevsel denklik yöntemi savunucuları, karşılaştırmalı hukuku olgusal bir yaklaşımla ${ }^{43}$ ele almaktadırlar ${ }^{44}$. Karşılaştırmalı hukukçunun odak noktası, hukuk kuralları değil, söz konusu kuralların yarattığı etki üzerindedir. Bir diğer ifadeyle, karşılaştırmalı hukukçu; öğretideki teorik nitelik arz eden tartışmalar yerine meydana gelen somut uyuşmazlıkların mahkemeler tarafından nasıl karara bağlandığını incelemesinde esas almaktadır. Bu doğrultuda, muhtelif hukuk sistemleri arasında gerçekleştirdiği karşılaştırma faaliyetini de mahkemelerin benzer

and Method (Oxford University Press 2014) 79 vd.) Nitekim bazı durumlarda çeşitli hukuk sistemlerinde uygulanan ve birbiri ile özdeş ya da benzer nitelikte olduğu kabul edilen hukuk kuralları, uygulama açısından çok farklı sonuçlar elde edilmesine yol açabilir. İşlevsel denklik yönteminin benimsendiği belirtilen çalışmalarda hâkim olan bu anlayış, söz konusu yöntemin; "hukuk kuralını esas alan yöntem", "hukukun kendi bağlamı içerisinde anlaşılması yöntemi”ne ilişkin öğretide yapılan ikili ayrımda, ilk başlığın altında kabul edilmesine neden olmuştur. Hukuk kuralını esas alan yöntemin gelişmesinde büyük katkıları olan Ernst Rabel'in çalışmaları, (detaylı bilgi için bkz. Basedow (n 2) 889 vd.) fikirsel anlamda David J. Gerber'in yöntem bilime ilişkin çalışmalarında sistematik bir iz düşüme kavuşmaktadır. Gerber, Rabel'in yaklaşımını, “...karşılaştırmalı hukuk araştırmacıları için bir reçete tanzim etmek gerekirse, bir hukuki sorunun iki ya da daha çok hukuk sisteminde nasıl çözümlendiğine bakılması ve söz konusu sorunun çözümünde hem benzerlik hem de farklılık arz eden hususların keşfedilmesi gerekliliği..." olarak özetlemektedir. (Bkz. David J. Gerber, 'Sculpting the Agenda of Comparative Law: Ernst Rabel and the Façade of Language' in A. Riles (ed), Rethinking the Masters of Comparative Law (2001) 199 vd.) Gerber, Rabel'in yöntem bilime ilişkin anlayışında, karşılaştırmalı hukuk araştırmalarının gerçekleştirilmesinde yabancı dil sorununun yol açabileceği engellerin öncelikle kaldırılması gerektiği inancını taşıdığını belirtmektedir. Bu doğrultuda, yazılı nitelikteki metinlerin kavramsal ve dilsel açıdan karşılaştırmalı bir hukuk araştırmasının gerçekleştirilebilmesi bakımından yeterli olmayacağını, ilgili yabancı hukukun mutlaka kendi bağlamı içerisinde incelenmesinin gerekliliğini de vurgulamıştır. (Bkz. Husa (n 20) 1100). Yasal uygulama hakkında yeterli derecede bilgi sahibi olmadan, hukuk kural ve kurumlarının anlaşılamayacağını belirten Rabel, aksi yönde yapılacak bir değerlendirmeyi, "kas sistemi olmayan bir iskelet”"e benzetmiştir. (Bkz. Husa (n 20) 1101). Bu doğrultuda Rabel, karşılaştırma faaliyetinin gerçekleştirileceği hukuk kuralının ya da mahkeme kararının, somut hukuki uyuşmazlığa nasıl uygulanacağının arz ettiği önemi vurgulamak istemiștir. Dolayısıyla, Rabel tarafından da hukukun kendi bağlamı içerisinde, ait olduğu kültürel yapı çerçevesinde anlaşılmasının gerekliliği ortaya koyulmuş olsa da; günümüzdeki işlevsel denklik yöntemine hâkim olan yaklaşımda da kabul edildiği üzere, söz konusu yaklaşım teoride hedeflendiği hâliyle her durumda uygulamaya geçirilememektedir. (Bkz. ibid $1100 \mathrm{vd}$.).

40 Michaels (n 32) 341.

41 İşlevsel denklik yöntemine ilişkin öğretide süregelen tartışmaların, metodolojik bir tartışmanın ötesine geçerek karşılaştırmalı hukukun çok farklı alanlarındaki çeşitli anlayışları da etkilediği yönünde detaylı bilgi için bkz. Michaels (n 32) $340 \mathrm{vd}$.

42 ibid $341 \mathrm{vd}$.

43 İşlevsel denklik yöntemi savunucularının, karşılaştırmalı hukuku olgusal bir yaklaşım ile ele almaları gerekliliğine ilişkin detaylı bilgi için bkz. Örücü (n 10) 29.

44 Farklı hukuk sistemleri arasındaki benzerliklere odaklanan olgusal yaklaşım; söz konusu benzerliklerin, ilgili hukuk sistemi açısından bir gereklilik sonucunda mı ortaya çıktığı yoksa tamamen rastlantısal bir şekilde ilgili hukuk sisteminde mi yer edindiğini anlayabilmemiz açısından yeterli gelmemektedir. Bkz. Michaels (n 32) 364 . 
durumlar karşısında üretmiş olduğu çözümleri temel alarak gerçekleştirmektedir ${ }^{45}$. Bu durum, gerek hukukun daha doğru şekilde anlaşılmasına gerekse de mahkeme kararlarının eleştirel anlamda geliştirilerek daha iyi biçimde değerlendirilebilmesine olanak sağlamaktadır ${ }^{46}$.

İkinci olarak, karşılaştırmalı hukuku işlevsel denklik yöntemi ile özdeşleştiren anlayış; sorunların olgusal bir yaklaşım ile değerlendirilmesini, toplumda hukuka atfedilen amaç çerçevesinde açıklamaktadır. Hukuk ve toplumun, birbiri ile yakın bir ilişki içerisinde olmasına rağmen, birbirinden ayrılabileceği olgusu unutulmadan, bu amacın benimsenmesi gerektiği kabul edilmektedir ${ }^{47}$.

Son olarak, işlevsel denklik yöntemi bir karşılaştırma ölçütü (tertium comparationis) olarak kullanılmaktadır ${ }^{48}$. Burada ifade edilmek istenen, karşılaştırma faaliyetini gerçekleştiren hukukçunun, kendi içinde yetiştiği hukuk sisteminin bakış açısıyla sınırlı olmadan, değişmez olarak ifade edilebilecek unsurlar üzerinden tarafsız bir araştırma faaliyeti yürütebilmesidir ${ }^{49}$. Zira bir hukuk kuralını ya da kurumunu karşılaştırma faaliyetine konu eden araştırmacının, ilgili kural ya da kurumu öncelikle kendi içinde bulunduğu hukuk sisteminin değer yargıları ile kavramaya çalışması, işin doğası gereği oldukça makul bir yaklaşımdır. Burada önemli olan, karşılaştırmalı hukukçunun böylesi bir anlayış ile karşılaştırma faaliyetine başlamış olduğunun bilincinde olması ve araştırmasını tarafsız bir şekilde sürdürebilmesine olanak sağlayan unsurlar üzerinden devam ettirebilme bilinciyle çalışmasını tamamlamasıdır ${ }^{50}$. Bu yaklaşım, sadece karşılaştırma faaliyetini gerçekleştirdiğimiz ve bize nispeten yabancı olan hukuk sistemi açısından değil, kendi içinde yetiştiğimiz hukuk sistemi bakımından da daha tarafsız değerlendirmelerde bulunabilmemize olanak sağlar ${ }^{51}$.

İşlevsel denklik yöntemi savunucularının oybirliği ile üzerinde uzlaştıkları bir husus olmamakla birlikte, bazı hukuk çevrelerinde, işlevsel denklik ölçütünün çalışmanın sonucunda bir değerlendirme ölçütü olarak da kullanılabileceği kabul edilmektedir ${ }^{52}$. Bu sayede, belli bir hukuki soruna ilişkin karşılaştırmaya konu edilen hukuklar arasında, hangi hukukun daha iyi işlev (better-law approach) gösterdiği anlaşılabilecektir. Bu sayede, farklı hukuk sistemleri arasında ulaşılan çözümler içerisinde en iyi olduğu düşünülen çözümün diğer sistemler tarafından benimsenme ihtimali de değerlendirilmiş olacaktır.

Bahsi geçen tüm bu amaçlara ulaşılmasındaki temel hedef; farklı hukuk sistemlerinin benimsendiği muhtelif toplumlardaki belirli sorunlara ilişkin, uygulama açısından nasıl bir çözüm üretildiğinin tespit edilebilmesidir. Başka bir ifadeyle, işlevsel denklik yöntemi; belirli bir soruna ilişkin menfaat çatışması durumunda hangi menfaatin üstün tutulduğuna yönelik incelemesini, üretilen çözümü esas alarak gerçekleştirmeyi hedeflemektedir. Bu sayede, söz konusu sorunu karşılaştırma faaliyetinin

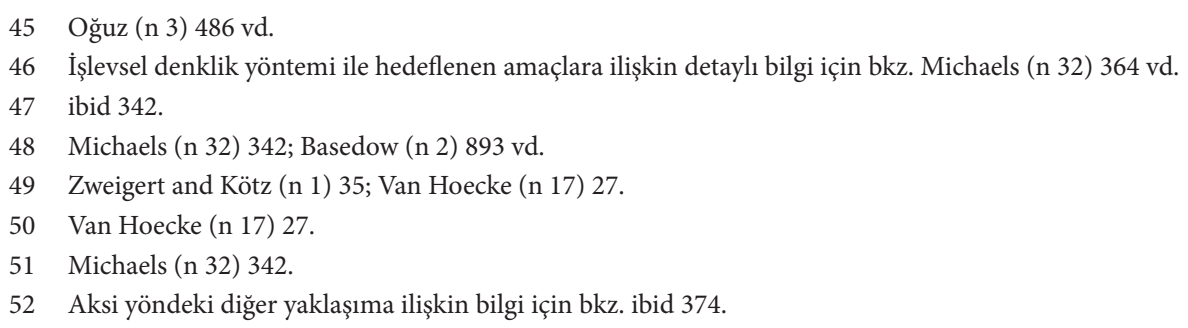


yürütüldüğü hukuk sisteminde yerleşik olan dogmatik yaklaşımlardan bağımsız bir şekilde kavrama olanağına kavuşmak da mümkün olmaktadır ${ }^{53}$. İşlevsel denklik yönteminin uygulanmasında, ilgili hukuki sorunun çözümüne yönelik olarak karşılaştırma faaliyetinin yürütüldüğü hukuk sistemindeki kural, kurum ve mahkeme kararlarının değerlendirilmesi gerekmektedir. Ancak burada ifade edilmek istenilen, karşılaştırmalı hukuk araştırmasının hukukun yazılı kaynakları ile sınırlı tutulması gerektiği değildir ${ }^{54}$. Zira hukukun yazılı kaynakları olarak nitelendirebileceğimiz hukuk kuralları ve mahkeme kararlarının kökenini; kültürel, sosyal, ekonomik ve özellikle ideolojik nitelikteki toplumsal hayatın dinamikleri oluşturmaktadır. Bu doğrultuda karşılaştırmalı hukuk araştırmasının başlangıç noktasını, hukuki soruna yönelik tesis edilmiş hukuk kuralı ya da mahkeme kararı değil; araştırmacının çalışması çerçevesinde çözmeyi hedeflediği hukuki sorunun toplumda üstlendiği işlev oluşturmaktadır. Bu yaklaşım çerçevesinde, işlevsel denklik yöntemi aynı zamanda karşılaştırılabilme faaliyetinin hangi unsurlar arasında yapılabileceğini de göstermektedir ${ }^{55}$. Sonuç olarak karşılaştırmalı hukuk araştırmacısı, karşılaştırma faaliyetini gerçekleştirdiği hukuk sitemindeki kural ve kurumların karşılaştırma faaliyetini gerçekleştirdiği diğer hukuk sistemleri ile arasında işlevsel anlamda bir denklik bulunup bulunmadığını incelemektedir. Bir diğer ifadeyle, karşılaştırma

53 Van Hoecke (n 17) 9; Samuel (n 39) 65.

54 Jaakko Husa, 'Farewell to Functionalism or Methodological Tolerance?' (2003) 67(3) Rabels Zeitschrift für ausländisches und internationales Privatrecht / The Rabel Journal of Comparative and International Private Law, 419, 423 vd. (Husa, Functionalism).

55 "Karşılaştırılabilme” (comparability) kavramı üzerindeki tartışmalar günümüzde hâlen geçerliliğini devam ettirmektedir. Bkz. Örücü (n 10) 19. "Karşılaştırılabilme" kavramına ilişkin tartışmanın çıkış noktasını, "karşılaştırmaya konu edilen hususların karşılaştırılabilir olması” şeklindeki totolojik olarak da nitelendirilebilecek olan fikir olușturmaktadır. Zweigert ve Kötz, karşılaştırmalı hukuku, farklı hukuk sistemlerindeki "karşılaştırılabilir" nitelikteki hukuki sorunlara ilişkin çözümlerin karşılaştırılması olarak tanımlamışlardır. Bkz. Zweigert and Kötz (n 1) 34. Ancak bu tanım, "karşılaştırılabilme" kavramına ihtiyaç duyulan katkıyı sağlamamaktadır. "Karşılaştırılabilme" kavramı, pek çok dilde "önemli ölçüde benzerlik ihtiva eden" ya da "çok farklı olmayan" anlamında kullanılmaktadır. Zira karşılaştırma faaliyetine konu edilen enstrümanlar arasındaki benzerlik (similarity), aralarında farklılık olmadığını (lack of difference); farklılık (difference) ise, aralarında benzerlik olmadığını (lack of similarity) göstermektedir. Dolayısıyla "karşılaştırılabilme" kavramı, kısmen birbirine benzeyen hukuk sistemleri, kurumları ya da kuralların bir arada değerlendirileceği durumları anımsatmaktadır. Bkz. Örücü (n 10) 20 vd. Nitekim 1900 yılında gerçekleşen Birinci Uluslararası Mukayeseli Hukuk Konferansında da ancak benzer konuların karşılaştırmalı hukuk araştırmalarına konu edilebileceği fikri üstün tutulmuştur. Öğretide de karşılaş̧ırmanın, verilen örneklerin karşılaştırılabilir ve ulaşılan sonuçların yorumlanabilir olduğu hâllerde gerçekleştirilebileceği kanaati hâkimdir. Ne var ki, "karşılaştırılabilme" kavramı ile "benzerlik" kavramı aynı anlama gelmemektedir. Zira "karşılaştırılabilme" faaliyetine birbirinden farklı durumların konu edilebileceği ya da sadece birbirine benzeyen durumlar arasında gerçekleştirilecek karşılaştırma faaliyeti sonucunda, birtakım farklılıkların da ortaya çıkmasının ihtimal dahilinde olduğu yönündeki yaklaşım, günümüzde de kesin bir netlik kazanmamıştır. Örücü (n 10) 21. Ayrıca, karşılaştırmalı hukuk araştırmasını gerçekleştiren kişinin söz konusu araştırmayı hangi amaçla yaptığı da "karşılaştırılabilme" kavramı açısından ayrıca ele alınmalıdır. Öğretide Örücü, bu durumu şu örnekler ile açıklamaya çalışmaktadır: Eğer amaç, birinin diğeri karşısında ne kadar mavi olduğunun ölçülmesi ise, bu durumda Deniz ile mavi bir terlik arasında dahi karşılaştırma faaliyeti gerçekleştirilebilir. Bu yaklaşımı karşılaştırmalı hukuk açısından sürdürdüğümüzde ise, mahkemelerin uyuşmazlıkları çözümlerken hangi yöntemleri benimsediği, nasıl bir anlayış doğrultusunda hüküm tesis ettiği, hükmün kesinleşmesinin ne kadarlık bir zaman dilimi içerisinde gerçekleştiğini anlayabilmek için, bir boşanma davası ile kiraya veren tarafından kiracısına karşı açılmış bir tahliye davasını karşılaşırabilir miyiz? sorusu yöneltilebilir. Nitekim her şeyin birbiri ile karşılaşıırmaya konu edilebilir olması, öğretide "karşılaştırılabilme" kavramı üzerinden yürütülen ve genişölçüde çeşitlilik gösteren tartışmanın devam etmesini engellememektedir. 
faaliyetine konu edilen hukuk kuralı ya da hukuki kurumun, kendi hukuk sistemi içerisinde nasıl bir toplumsal işlev üstlendiği, araştırmacı tarafından anlaşılmaya çalışılmaktadır ${ }^{56}$.

Somutlaştırmak gerekirse, işlevsel denklik yöntemini benimseyen bir hukukçu ${ }^{57}$, "A hukuk sistemindeki hangi kurum, B hukuk sisteminde incelenen kuruma denk bir işlev üstlenmektedir?" sorusuna yanıt aramaktadır ${ }^{58}$. Örneğin, A hukuk sisteminde boşanma kurumunu inceleyen karşılaştırmalı hukukçu, B hukuk sisteminde de kişiyi artık içinde bulunmak istemediği bir evlilik birliğinin bağlarından kurtaracak, denk bir işlev üstlenen bir kurum arayışında olacaktır. Öğretide Örücü, bu yaklaşımı "işlevsel-kuramsal" yaklaşım olarak ifade etmektedir ${ }^{59}$. "İşlevsel-kuramsal" yaklaşımın toplumsal bir anlayış doğrultusunda ele alındığı ve söz konusu yaklaşımın diğer ayağını oluşturan hâller ise öğretide Örücü tarafından, "sorun çözme" yaklaşımı olarak nitelendirilmektedir ${ }^{60}$. İşlevsel-kuramsal yaklaşımın sorun çözme ayağı, "S hukuki sorununa karşı A, B ya da C hukuk sistemlerinde hangi çözüm üretilmektedir?” sorusu ile somutlaştırılabilir. Örneğin, evlilik birliğinin sona ermesinden sonra boşanma sebebiyle yoksulluğa düşecek olan tarafın korunması sorunu A, B ya da C toplumunda nasıl çözümlenmiştir? Bahsi geçen hukuki sorun, yoksulluk nafakası ile, devletin sunduğu sosyal sigorta olanakları ile yahut geleneksel aile yapısı içerisindeki yardıma ihtiyacı olan eşe katkı sağlanması şeklinde çözülmeye çalışılmış olabilir ${ }^{61}$. İşlevsel denklik yönteminin, iki farklı görünümü olarak kabul edilen bu yaklaşımlar sayesinde karşılaştırmalı hukukçu, işlevsel açıdan denk özellikler ihtiva eden ya da aynı sorunun çözümüne ilişkin benzer görevler üstlenen kurumları değerlendirerek, karşılaştırma faaliyetini gerçekleştirdiği toplumların hukuk sistemleri arasında benzerlik olup olmadığına karar verebilecektir ${ }^{62}$. Ne var ki, karşılaştırma faaliyetinin konusunun, muhtelif hukuk sistemlerindeki kural, kurum ya da mahkeme kararlarının karşılaştırılması yerine; söz konusu sorunun toplumda nasıl çözümlendiği üzerine yöneldiği durumlarda, işlevsel bakımdan denklik yönteminin tek başına uygulanması yeterli olmayacaktır ${ }^{63}$.

Ayrıca, karşılaşılan sosyal sorunların dünyanın her yerinde benzer olduğu yönündeki anlayış, ancak sosyo-ekonomik yapılanmanın birbirine paralel bir gelişim gösterdiği toplumlar açısından iyimser bir varsayım olarak kabul edilebilir ${ }^{64}$. Tarihsel açıdan hukuk sisteminde farklı bir yapılanmanın esas alındığı ya da ideolojik motiflerin veya dini değerlerin hukuk öğretisinde rol oynadığı toplumlarda ortaya çıkan sosyal sorunları, dünyanın diğer coğrafyalarında karşılaşılan sorunlar ile benzer nitelikte kabul etmek, her durum için geçerli bir yaklaşım olmayacaktır ${ }^{65}$. Nitekim, işlevsel denklik yönteminin karşılaştırmalı hukuk çalışmalarında esas alınması gerektiğini kabul eden yaklaşım da bu durumun bilincindedir ki; tüm toplumlar bakımından evrensel şekilde çözümlenme eğilimi olan

56 Husa, Functionalism (n 54) 423 vd.

57 Örücü (n 10) 29.

58 ibid 29.

59 ibid 29.

60 ibid 29.

61 Örücü, Eski ve Yeni (n 2) 85.

62 ibid 85.

63 Van Hoecke (n 17) 10.

64 Van Hoecke (n 17)10; Oğuz (n 3 ) 496 vd.

65 Oğuz (n 3) 497. 
olayları ağırlıklı olarak karşılaştırma faaliyetine konu etmektedir ${ }^{66}$. Kendine özgü nitelik gösteren diğer durumlarda ise, ilgili hukuki soruna ilişkin üretilen çözümü, kanuni çerçevesinden tamamen ayırıp ya da söz konusu çözümün bir arada ele alınmasını gerektiren sosyo-ekonomik ya da tarihsel bağlamından çıkararak, işlevsel denklik yöntemi çerçevesinde karşılaştırma faaliyetine konu etme imkânı bulunmamaktadır ${ }^{67}$. Böylesi durumlarda, karşılaştırmalı hukukçunun aşağıda ele alınmaya çalışılacak olan diğer yöntemlerden de istifade etmek suretiyle araştırma alanını genişletmesi gerekmektedir.

İşlevsel denklik yönteminin, belirli bir hukuki soruna ilişkin farklı sistemlerde getirilmiş çözümleri değerlendirirken, söz konusu çözümleri ilgili hukuk sisteminin kültürel bağlamından mümkün olduğunca ayrı bir şekilde ele alan yapısı; bu yöntemi, diğer yöntemlere kıyasla daha kolay uygulanabilir bir hâle getirmektedir ${ }^{68}$. Karşılaştırmalı hukuk çalışmasını yürütürken karşılaşma ihtimali oldukça çok olan güçlükleri, çalışmanın başında benimsediğiniz yöntem sayesinde azaltmış olmak, söz konusu alanda araştırma yapmak isteyen pek çok hukukçu bakımından, işlevsel denklik yönteminin daha çok tercih edilmesini sağlayabilir. Ayrıca, aşağıda ele alınacak olan hukukun kendi bağlamı içerisinde anlaşılmasına ya da tarihsel yaklaşıma kıyasla, işlevsel denklik yöntemi; araştırmacının daha yaratıcı bir çalışma gerçekleştirmesine uygun olan ortamı da kendisine sağlamaktadır ${ }^{69}$. Ne var ki, bu durum aynı zamanda söz konusu yöntemin benimsendiği çalışmaların ilgili hukuki soruna ilişkin açıklayıcılık açısından daha sınırlı kalmasına da yol açmaktadır.

\section{B. YAPISAL YÖNTEM}

İşlevsel denklik yöntemi, farklı hukuk sistemlerinde üretilen çözümlerin sadece belirli hukuki sorunlar ile sınırlı olmak koşuluyla birbirleriyle karşılaştırılabilmesine olanak sağlamaktadır. Bir başka ifadeyle, karşılaştırmalı hukuk araştırmalarında işlevsel denklik yöntemi, sadece mikro-karşılaştırma olarak nitelendirilen aşamaya ilişkin çözüme ulaşmamıza imkân vermektedir. Yapısal yöntem (structural method) ise, hukuk sistemleri arasında daha bütüncül bir yaklaşım ile gerçekleştirilecek olan karşılaştırma faaliyetlerine yönelik çözüm üretilmesini hedeflemektedir. Örneğin, hukuk sistemleri çeşitli ölçütler doğrultusunda hukuk ailelerine ayrılırken, yapısal yöntemden istifade edilmektedir. Yapısal anlamda yeterli derecede ortak özellik ihtiva eden farklı hukuk sistemleri, aynı hukuk ailesinin üyesi olarak kabul edilirler ${ }^{70}$. Somutlaştırmak gerekirse, iç hukuklarında birbirinden

66 Michele Graziadei, 'The Functionalist Heritage' in Pierre Legrand and Roderick Munday (eds), Comparative Legal Studies: Traditions and Transition (Cambridge University Press 2003) $108 \mathrm{vd.}$

67 Van Hoecke (n 17) 10.

68 Van Hoecke (n 17) 11.

69 Van Hoecke (n 17) 11.

70 Van Hoecke (n 17) 12; Basedow (n 2) 888. Elbette, tarihsel gelişmeler ve bunun yol açtığı değişimler sonucunda hukuk sistemlerinin, mensubu oldukları hukuk ailesi değișebilir. Örneğin, Türk hukuku, Osmanlı İmparatorluğu zamanında İslam hukuku (dinsel) grubunda iken, Tanzimat'tan sonra, karma sistemlerden olmuş, cumhuriyetin ilanından sonra ise, Kara Avrupası grubuna geçmiştir. Bir hukuk sisteminin içinde bulunduğu grubu belirleyen unsurlarla ilgili detaylı bilgi için bkz. Esin Örücü, 'Karşılaştırmalı Hukukçu Gözüyle İskoç Hukuk Sistemi' (1990) 18 İstanbul Üniversitesi Mukayeseli Hukuk Araştırmaları Dergisi, 71, 72. (Örücü, Karşılaştırmalı). Öğretide Oğuz’a göre, iki farklı hukuk düzeni aynı tipik yapı ve özelliklere sahip ise, söz konusu düzenler arasında bir akrabalık ilişkisinden bahsetmek mümkün olabilir. Bu 
çok farklı düzenlemeler gerçekleştirmiş olan hukuk sistemleri, Kara Avrupası'nda hâkim olan civil law hukuk anlayışı ve hukuki düşünme yöntemini benimsemiş olmaları sebebiyle, aynı hukuk ailesinin üyesi olarak kabul edilirler. Yahut aralarında önemli yaklaşım farklılıkları olmakla birlikte, köken itibariyle Roma hukukuna dayanan hukuk sistemleri de yine yapısal yöntem sayesinde kendi içlerinde bir bütünlük arz etmekte ve özel hukuktaki yapılanması, Roma hukukuna dayanmayan diğer sistemlerden ayrılmaktadır ${ }^{71}$.

Yapısal yöntem sayesinde araştırmacı, karşılaştırma faaliyetine konu edilen hukuk sistemini hem söz konusu sistemin içerisinde yetişmiş hem de sisteme dışarıdan bakan bir hukukçu gözüyle değerlendirme olanağına sahip olur ${ }^{72}$. Bu sayede, söz konusu sistemin içerisinde yetişmiş bir hukukçu bakış açısıyla öncelik hem hukuk norm ve kurallarına verilirken; hem de sistemi dişarıdan değerlendiren bir hukukçu bakış açısı sayesinde; araştırmacı, bir toplum bilimci gibi hareket ederek yasal çoğulculuk açısından da ilgili sistemi değerlendirebilme imkânını haiz olur ${ }^{73}$.

Somutlaştırmak gerekirse, toprak hukuku ile ilgili dünya genelindeki tüm hukuk sistemlerini karşılaştırma faaliyetine konu etmeyi planlayan ve ilgili hukuk sistemlerinde üretilen çözümler doğrultusunda hukuk sistemlerini gruplandırmayı hedefleyen bir çalışma yapılacağını düşünelim. Böylesi bir çalışmada, araştırmacı ilk olarak Kara Avrupası hukuk sistemi ile common law hukuk sistemine dayalı temel bir ayrım gerçekleştirmeyi seçebilir. Bazı araştırmacılar ise, kamu hukuku ve özel hukuk ayrımına dayanarak çalışmalarına başlamayı tercih edebilir. Zira, 20. yüzyılda Doğu Avrupa ülkelerinde hâkim olan sosyalist ya da komünist anlayış, üretim araçları üzerindeki tasarruf yetkisini sorununu, kamu hukuku ile irtibatlandırmaktaydı. Bireylerin özel mülkiyetine izin vermeyen anlayışı, hukuk sistemi bakımından birbirine pek benzemeyen ve aynı hukuk ailesi içerisinde nitelendiremeyeceğimiz ülkelerin konuya ilişkin yaklaşımları çerçevesinde değerlendirirsek; Birleşik Krallık bakımından sadece teorik bir anlam taşımakla birlikte Kraliçe’nin resmi olarak tüm toprak parçasına sahip olması, Demokratik Kongo Cumhuriyeti’nde ise vatandaşların özel mülkiyet hakkına sahip olmasına rağmen, şirketlerin ve yabancıların sadece yirmi beş yıl süre ile benzer nitelikteki hak ve yetkilere sahip olabilmesi ve Çin Halk Cumhuriyeti’nde ise, devletçi bir anlayış ile yine özel mülkiyetin çok sınırlı bir şekilde bireylere tanınması hâli, birbiriyle karşılaştırılabilir niteliktedir ${ }^{74}$.

Hukuk çevrelerinde Kara Avrupası hukuk sistemi ile common law hukuk sistemine dayanan yerleşik ayrım, özel mülkiyete izin verilen toplumlar açısından mikro düzeyde bir karşılaştırma gerçekleştirilmesine imkân sunmakla birlikte; dünya genelindeki bütün hukuk sistemlerini alışkın olduğumuz bu ayrım doğrultusunda tasnif etme imkânı bulunmadığı anlaşılmaktadır. Bir hukuk sisteminin hangi grupta bulunduğuna ilişkin geliştirilen, sisteme özelliğini veren ve sisteme özgü

tipik yapı ve özelliklerin neler olabileceği ise, tanımlayıcı diğer unsurların belirlenmesi yoluyla açıklanacaktır. Akrabalık ilişkilerinin kurulması sonrasında ise, hukuk aileleri ve hukuk çevrelerinin oluşacağı yönünde bkz. Oğuz (n 3) 481, 484.

72 Samuel (n 39) 106.

73 Yasal çoğulculuk yaklaşımının temelinde, devletin yasa yapabilen tek yetkili olmadığı ve sosyal düzenin, genellikle çeşitli normatiflik kaynaklarına dayandığı varsayımı yer almaktadır. Bu bakış açııı, araştırma faaliyetine konu edilen toplumlar hakkında daha derinlikli bilgi sahibi olunmasının önemini göstermektedir. Bilgi için bkz. Örücü, Eski ve Yeni (n 2) 90.

Toprak hukuku üzerinden verilen söz konusu örnek için bkz. Van Hoecke (n 17) 12. 
hukuki düşünce biçiminin nasıl yapılandığından hareket eden ölçütler, çoğu zaman sadece özel hukuk çerçevesinden ele alınmaktadır. Hatta söz konusu ölçütler bir hukuk sisteminin hangi gruba ait olduğuna ilişkin bütüncül bir değerlendirme yapılmasına dahi her durumda olanak vermemekte; ilgili hukuki sorunun, aile hukukuna mı, toprak hukukuna mı, ya da miras hukukuna mı ilişkin olduğunun tespiti doğrultusunda ayrıca bir değerlendirmeye ihtiyaç duyulmaktadır. Bu yaklaşım çerçevesinde yukarıda verdiğimiz örneği yeniden ele almak gerekirse, Birleşik Krallık, Demokratik Kongo Cumhuriyeti ve Çin Halk Cumhuriyeti’nin mülkiyet hakkına ilişkin yaklaşımlarının kendi içlerinde bir hukuki grup oluşturabileceği yönünde bir çıkarım yapılabilir ${ }^{75}$. Bu durum, muhtelif ayrım ve ölçütlerden istifade edilerek gerçekleştirilecek bütünsel değerlendirmeler sonucunda, hukuk sistemleri arasında belirgin derecede kesin bir nitelik gösteren ve oldukça ilginç sonuçlara ulaşmamıza olanak sağlayabilir ${ }^{76}$.

\section{ANALITIK YÖNTEM}

Hukuk sistemleri, çeşitli hukuki kurumlar altında farklı nitelikteki pek çok yasal hakkı ihtiva ederler. Örneğin, mülkiyet hakkı, sahibine şey üzerinde dilediği gibi kullanma, yararlanma ve tasarruf etme imkânını vermektedir. Mülkiyet hakkının daha derinlemesine ele alınması hâlinde ise, farklı hukuk sistemleri çerçevesindeki intifa hakkına, oturma hakkına ya da irtifak haklarına ilişkin düzenlemeler arasındaki benzerlik yahut farklılıkları daha doğru şekilde tespit etme olanağına sahip oluruz. Somutlaştırmak gerekirse, common law hukuk sistemini benimsemiş olan ülkelerde oldukça yaygın bir uygulama alanına sahip olan ve mülkiyetin bölünmesi esasına dayanan trust kurumunun, Kara Avrupası hukuk sistemine oldukça yabancı olduğu düşünülebilir. Zira bu yapı sayesinde, trustın konusunu oluşturan malvarlığı unsurlarının mülkiyeti inançlı mülkiyet esası çerçevesinde güvenilen kişide bulunurken; söz konusu unsurların güvenilenin kendi malvarlığından ayrı, özel bir malvarlığı oluşturması gerekmektedir ${ }^{77}$. Ne var ki, trust yapısını Türk hukukundaki kurumlar ile analitik yöntem çerçevesinde karşılaştırdığımızda; Sermaye Piyasası Kanunu’nun 31/B maddesinin 6. fikrasında yer alan yapının ${ }^{78}$, trust olarak nitelendirilebilmesi için gereken zemini sağladığı söylenebilir ${ }^{79}$.

Analitik yöntem, farklı hukuk sistemleri arasındaki benzerlik ya da farklılıkların derin bir yaklaşım çerçevesinde daha iyi anlaşılmasını hedeflemektedir. Bu sayede, kültürel bağlamda birbirinden

75 Van Hoecke (n 17) 12 vd. Aynı ölçütler ile kamu hukuku açısından bir değerlendirme yapılması gerektiğinde, devletin yönetim şekli, üniter mi federal bir yapıda mı olduğu, anayasa mahkemesinin yetkileri, insan hak ve özgürlüklerine ilişkin genel yaklaşımı vb. nitelikteki pek çok ölçütün daha bir arada değerlendirilmesi gerekmektedir. Bkz. ibid 12 vd.

76 ibid $12 \mathrm{vd}$.

77 Gökçe Kurtulan Güner, Trust ve Türk Hukuku Açısından Değerlendirilmesi (On İki Levha 2020) 109 vd.

78 Sermaye Piyasası Kanunu, Kanun Numarası: 6362, Kabul Tarihi: 06.12.2012, RG 30.12.2012/28513. 6362 sayılı Sermaye Piyasası Kanunu’nun 31/B maddesinin 6. fikrası; “Teminat konusu varlıklar, teminat yöneticisinin mal varliğından ayrıdır ve ayrı izlenir. Teminat konusu varlıklar, teminat yöneticisinin borçları nedeniyle kamu alacakları için olsa dahi haczedilemez, rehnedilemez, iflas masasına dâhil edilemez ve üzerlerine ihtiyati tedbir ve ihtiyati haciz konulamaz" şeklindedir.

79 Gökçe Kurtulan Güner, 'Türk Hukuku için Yeni (?) Bir Kurum: Teminat Yöneticisi' (İstanbul 2021) <https://law.khas. edu.tr/tr/turk-hukuku-icin-yeni-bir-kurum-teminat-yoneticisi> Erişim Tarihi: 10.08.2021. 
oldukça farklı bir yapı ihtiva eden hukuk sistemlerinin dahi, karşılaşılan hukuki sorunları kendi yapısı içerisinde en elverişli şekilde nasıl çözümlediği açıklanabilecektir ${ }^{80}$.

\section{HUKUKUN KENDI BAĞLAMI IÇERISINDE ANLAŞILMASI YÖNTEMI}

1900 yılında gerçekleşen Birinci Uluslararası Mukayeseli Hukuk Konferansı sonrasında, karşılaştırmalı hukuk araştırmalarında uygulanabilecek yöntemler, öğretide bazı araştırmacılar tarafından temel itibariyle ikiye ayrılarak ele alınmıştır ${ }^{81}$. Bu yöntemlerden ilki, hukuk kuralını esas alan yöntem (rule oriented method), diğeri ise, hukukun kendi bağlamı içerisinde anlaşılmasını (the law in context method) esas alan yöntemdir ${ }^{82}$. Öğretide yapılan bu ikili ayrım, yukarıda ele aldığımız diğer yöntemleri dışlamadığı gibi, söz konusu yöntemleri de bu ikili tasnif altında değerlendirmenin gerekliliğine inanmaktadır.

Hukukun kendi bağlamı içerisinde anlaşılmasına öncelik veren yöntem, bir dizi ihtimali bir arada değerlendirerek ilgili hukuki soruna ilişkin üretilen farklı çözümleri karşılaştırmaktadır. "Hukukun kendi bağlamı içerisindeki” ifadesi ile, tarihsel, sosyolojik, antropolojik, psikolojik ya da benzer nitelikteki hukuk dışı diğer disiplinlerin de söz konusu hukuki sorunun çözümünde bir ölçüt olarak değerlendirilmesi gerekliliği kastedilmektedir. Elbette, burada da öncelikli olarak karşılaştırma faaliyetine konu edilen hukuk kuralını ya da hukuki kurumu, yürürlükte olan yasal düzenlemeler, mahkeme kararları ${ }^{83}$ ve hukuk öğretisi çerçevesinde ele almak gerekmektedir. Ne var ki, burada karşılaştırma faaliyeti, yasal düzenlemeler ve mevcut uygulama ile sınırlı kalmamakta; yukarıda bahsi geçen bir dizi disiplin ile ihtiyaç duyulan diğer disiplinlerden de istifade edilerek ilgili hukuki sorun ayrıca değerlendirilmektedir. Bu doğrultuda karşılaştırmalı hukuk araştırmacısı, öncelikle tecrübesi doğrultusunda çalışmasında benimsemeyi tercih ettiği yöntemi belirlemelidir. Sonrasında ise, edindiği bilgiyi, zamansal bir sınırlama içerisinde bulunup bulunmadığı ve hedeflenen bilgiye ulaşmasını sağlayacak mali olanakların yeterliliği çerçevesinde, diğer disiplinlerin de yardımıyla en doğru şekilde kullanarak çözüme ulaştırmalıdır ${ }^{84}$. Hukukun kendi bağlamı içerisinde anlaşılması

80 Analitik yöntem ile ilgili detaylı bilgi için bkz. Van Hoecke (n 17) $13 \mathrm{vd}$.

81 Husa (n 20) 1098. Yazar, karşılaştırmalı hukuk araştırmasına ilişkin öğretide üzerinde uzlaşılmış herhangi bir tanımın verilemeyeceğini belirtmekle beraber; common law ve Kara Avrupası hukuk sistemlerinde karşılaștırmalı hukuk çalışmalarında uygulanacak yöntemlerin de arz ettikleri farklılıklar nedeniyle birbirinden ayrıştırılabileceğini belirtmektedir. Bkz. ibid 1098. Konuya ilişkin ayrıntılı bilgi için bkz. dpn. 39.

82 Husa (n 20) 1098.

83 Mahkeme kararlarının karşılaştırma faaliyetine konu edilmesi bakımından dikkat edilmesi gereken husus ise, toplum içinde yaşayan hukukun doğru bir şekilde anlaşılabilmesi açısından mahkeme kararlarının önemli olduğu, ancak her zaman için yeterli olmadığı hususudur. Zira bazı hukuki sorunların varlığı toplumdan topluma değişiklik gösterebilir ve her toplumda aynı tür sorunlarla karșılașılması muhtemel olmayabilir. Ya da ilgili toplumda söz konusu hukuki sorunun nasıl çözümlenmesi gerektiği herkesin bilgisi dahilinde olduğundan, bu konuda ortaya çıkan uyuşmazlıklara ilişkin yargı sistemine müracaat edilmesine gerek kalınmıyor olabilir. Öğretideki bu yaklaşım, Van Hoecke tarafından şu şekilde betimlenmiştir: Mahkemeler, toplumsal düzenin sağlanması bakımından birer hastane gibi görev yaparlar. Bu nedenle, sadece hasta olanlar mahkemeye başvururlar; sağlıklı olanlara ilişkin herhangi bir mahkeme kaydına rastlanmaz. Dolayısıyla, karşılaştırmalı hukuk araştırmalarında hukuku kendi bağlamı içerisinde anlamaya çalışan yöntem; mahkeme kararlarını, toplumsal açıdan da ayrıca değerlendirdikten sonra hukuksal gerçekliğe ulaşabilir. Detaylı bilgi için bkz. Van Hoecke (n 17) 17 vd.

Van Hoecke (n 17) 17. 
yöntemi, öğretide Sacco tarafından, "hukuku biçimlendirici" bir nitelik arz eden tüm unsurların bir arada değerlendirilmesi sonucunda ancak mevcut sistem hakkında en doğru bilgiye sahip olabileceğimiz yaklaşımı üzerine şekillendirilmiştir ${ }^{85}$. Bu doğrultuda, yasa koyucu tarafından çıkarılan anayasa dahil tüm yasal düzenlemeler, mahkeme kararları ve hukuk öğretisi gibi açıkça belirtilmiş unsurlar dışında, her zaman açıkça belli olmayan ve ilgili toplumda hâkim olan anlayış doğrultusunda değişebilen ya da gelişebilen unsurlar da hukukun yorumlanmasında ve uygulanmasında büyük role sahiptir ${ }^{86}$.

Sonuç olarak, hukukun kendi bağlamı içerisinde anlaşılmasına ilişkin yöntem, ilgili hukuki sorun bakımından hukukun nasıl anlaşılması, yorumlanması ve uygulanması gerektiği açısından önemli bir kaynak teşkil etmektedir ${ }^{87}$. Söz konusu yöntem, ilgili hukuk sistemi içerisinde karşılaştırmaya konu edilen hukuki sorununun neden kaynaklandığını ve ulaşılan çözümün de halihazırda neden böyle olduğunu anlamamıza olanak sağlamaktadır.

Öğretide Van Hoecke’ye göre, hukukun kendi bağlamı içerisinde anlaşılmasına ilişkin yöntem, çoğu zaman diğer yöntemlerden ayırt edilemeyecek kadar onları tamamlayıcı bir nitelik arz etmektedir ${ }^{88}$. $\mathrm{Bu}$ yaklaşım doğrultusunda karşılaştırmalı hukuk araştırmalarında uygulanabilecek olan diğer yöntemleri de değerlendirdiğimizde, özellikle işlevsel denklik yönteminin ele aldığı hukuki soruna kendi bağlamı içerisinde bir çözüm üretmeye çalıştığı söylenebilir. Nitekim öğretide Örücü, hukukun kendi bağlamı içerisinde anlaşılması yöntemini, hukukun toplumsal bir anlayış doğrultusunda ele alınması olarak nitelendirmekte ve yukarıda da belirtildiği üzere bu durumu, işlevsel yöntemin bir çeşidi olarak görmektedir ${ }^{89}$. Dolayısıyla, karşılaşılan toplumsal nitelikte bir sorunun; işlevsel denklik yöntemi çerçevesinde hangi hukuki kurum altında değerlendirileceğinin tespiti de bir dereceye kadar hukukun kendi bağlamı içerisinde anlaşılması gerekliliğine ilişkin yöntemden faydalanılarak, çözüme ulaştırılmaktadır ${ }^{90}$. Benzer şekilde, yapısal yöntem ve analitik yöntem de çoğu zaman türdeş ihtiyaçlardan ötürü, hukukun kendi bağlamı içerisinde anlaşılması yönteminden istifade etmektedir ${ }^{91}$.

\section{E. TARIHSEL YÖNTEM}

Tarihsel yöntem, hukukun kendi bağlamı içerisinde anlaşılmasına ilişkin yöntemin bir görünümü olarak nitelendirilmektedir. Nitekim tarihsel yöntem çerçevesinde, bir hukuk kuralının ya da hukuki kurumun gösterdiği işlevin halihazırda doğru bir şekilde anlaşılabilmesi, söz konusu kural ya da

85 Rodolfo Sacco, 'Legal Formants: A Dynamic Approach to Comparative Law' (1991) American Journal of Comparative Law (part II) 343, $384 \mathrm{vd}$.

86 ibid $386 \mathrm{vd}$.

87 Van Hoecke (n 17) 17.

88 ibid 16.

89 Örücü (n 10) 25.

90 Van Hoecke (n 17) 16.

91 ibid 16. 
kurumun tarih boyunca nasıl bir değişim ya da gelişim gösterdiğine bağlanmıştır ${ }^{92}$. Karşılaştırmalı hukuk araştırmacılarının, hukuk tarihi ile ilgili ihtiyaç duyabilecekleri bilgiyi temin etmeleri, yukarıda bahsi geçen diğer yöntemlere kıyasla daha kolaydır ${ }^{93}$. Zira tarihsel yöntem, çoğu zaman hukuk dışı disiplinlerden olan ekonomi, sosyoloji, psikoloji vb. diğer disiplinlerden istifade ettiği bilgileri de kendi içinde içselleştirerek okuyucuya sunduğu için; araştırmacıya hem tarihsel hem de diğer disiplinler bağlamında hukuki sorunu bütüncül bir şekilde, adeta kendi bağlamı içerisinde anlayabilme firsatını sunar ${ }^{94}$.

Tarihsel yöntem sayesinde, sadece yürürlükte olan hukukun şimdiki durumuna nasıl ulaştığına ilişkin bilgi sahibi olmayız. Aynı zamanda, benzer yönde anlayışların farklı hukuk sistemlerinde de geçmişte benimsenip benimsenmediğini; eğer benimsendiyse de bu eğilimin günümüzde hâlen devam edip etmediğini ve buradaki değişim ya da gelişimin kaynağını da öğrenme imkânına sahip oluruz ${ }^{95}$. Somutlaştırmak gerekirse, İngiliz, Fransız ve Alman hukuk sistemlerinde sözleşmenin yorumu birbirinden farklı şekilde anlaşılmaktadır. Örneğin, İngiliz hukukunda sözleşmenin metni (as it appears from the text of the contract) esas alınırken; Fransız hukukunda, sözleșenlerin gerçek iradesi (the will of the contracting parties) sözleşmenin yorumunda temel alınmaktadır. Alman hukukunda ise, İngiliz hukukunda benimsenen objektif yaklaşım ile Fransız hukukunda egemen olan sübjektif yaklaşımın arasında, adeta hem objektifleştirilmiş bir sübjektif anlayışın hem de sübjektifleştirilmiş bir objektif anlayışın benimsendiği söylenebilir ${ }^{96}$. Zira Alman hukukunda, ilgili sözleşmeyi okuyan makul bir üçüncü kişinin sözleşmeye atfedeceği anlam (the meaning a reasonable outsider would assume to be meant) esas alınmaktadır. Konuyu tarihsel yaklaşım çerçevesinde değerlendirdiğimizde ise, Fransız hukukuna egemen olan sübjektif anlayışın, 19. yüzyılın ikinci yarısına kadar Alman ve İngiliz hukuklarında egemen yaklaşım olduğu ve 18. yüzyılın sonundan itibaren de Fransız hukukunda objektif anlayışın yaygınlaşmaya başladığğ görülmektedir ${ }^{97}$. Dolayısıyla gerek objektif gerekse de sübjektif anlayışın, yakın dönem tarihinde söz konusu ülkelerin tamamında hâkim olmuş

92 ibid 18.

93 Zira bir hukuk kuralı ya da hukuki kuruma ilişkin gerçekleştirilen araştırmada, yabancı kaynaklarda çoğunlukla söz konusu kural yahut kurumun hangi ihtiyaçtan kaynakladığı ve nasıl bir süreç içerisinde geliştiği, çalışmanın başlangıç kısmında ayrı bir bölümde ele alınmaktadır. Karşılaştırmalı hukuk araştırmalarının özellikle geçtiğimiz yirmi yıl içerisinde giderek önem kazandığı ve 2013 ylı itibariyle Oxford Üniversitesi’nin Karşllaştırmalı Hukuk Tarihi (Comparative Legal History) ile ilgili çalışmaları ayrı bir dergide yayınlamaya başlamış olmasının, konuya atfedilen değerin önemli bir göstergesi olduğuna ilişkin bkz. ibid 18 ve dpn. 23.

94 ibid 19.

95 ibid 19.

96 İlgili örneğin, Fransız, İngiliz ve Alman hukuk sistemlerinde karşılaştırılmasına ilişkin detaylı bilgi için bkz. Mark Van Hoecke, 'Deep Level Comparative Law' in Mark Van Hoecke (ed), Epistemology and Methodology of Comparative Law (2004) 178 vd. (Van Hoecke, Deep).

97 Sözleşmenin yorumlanmasındaki farklılıklara dikkat çeken örnek ile ilgili detaylı bir değerlendirme için bkz. Van Hoecke (n 17) 19, 23 vd.; Van Hoecke, Deep (n 96) 179 vd. Sözleşmelerin yorumuna ilişkin Fransız, İngiliz ve Alman hukuk sistemlerinde farklı anlayışların hâkim olmasında, aynı zamanda söz konusu toplumlarda, sözleşme kavramına atfedilen anlamı nasıl algılamamız gerektiği, bireysel özgürlükler ile alışveriş güvenliği arasında kurulmaya çalışılan dengede hangisine öncelik verildiği, hâkimin ilgili uyuşmazlıklarda ne kadar etkin bir görev üstlendiği gibi birçok farklı tartışmanın da doğrudan ya da dolaylı katkısının bulunduğuna ilişkin bkz. Van Hoecke, Deep (n 96) 189. 
olması; söz konusu teorilerin ilgili hukuk sistemlerine olan bağlılıklarını değil, belirli bir tarihsel döneme olan bağlılıklarını göstermektedir ${ }^{98}$.

Geçen zaman içerisinde birbiri ile sürekli olarak bir rekabet içerisinde bulunan sübjektif ve objektif yaklaşımlar arasında, birinin diğerine kıyasla üstün gelmesi hususunda Fransız, İngiliz ve Alman hukuklarındaki tarihsel sıralamanın, farklılık gösterdiği anlaşılmaktadır. Sonuç olarak, tarihsel yöntem sayesinde hukuk sistemleri arasındaki benzerlik ve farklılıkların, daha derinlemesine incelenmesi olanağına kavuşulmaktadır.

\section{SONUÇ}

Bu çalışmada, karşılaştırmalı hukuk araştırmalarında başvurulabilecek belli başlı yöntemleri genel özellikleri itibariyle ele almaya çalıştık. Öncelikle, söz konusu yöntemleri öne çıkan özellikleri çerçevesinde kısaca değerlendirmek; sonrasında ise, konuya ilişkin öğretide ileri sürülen eleştirilere mümkün olduğunca yer vermek istemekteyiz. Ancak belirtmek isteriz ki, uygulanacak yöntem konusunda getirilen eleştiriler esas itibariyle karşılaştırmalı hukuk araştırmalarının merkezinde bulunan işlevsel denklik yöntemine ilişkindir.

İşlevsel denklik yöntemi, halihazırdaki hukuki sorunu merkeze alarak; söz konusu sorunun farklı yargı çevrelerinde nasıl bir hukuki yol çerçevesinde çözümleneceğini ve bu doğrultuda, elde edilen sonuçların birbiri ile benzerlik mi farklılık mı ihtiva ettiği üzerine yoğunlaşmaktadır ${ }^{99}$. Analitik yöntem ise, içinde yetiştiğimiz hukuk sistemi bakımından ilk bakışta alışılagelmedik özellikler ihtiva eden hukuk kural ve kurumları ile kendi hukuk sistemimiz arasında gerçekleştirilen karşılaştırma faaliyetinde, temel kavramlar üzerinden benzerliklerin ya da farklılıkların nasıl ele alındığının anlaşılmasına olanak sağlamaktadır ${ }^{100}$. Yapısal yöntem ise, hukukun kendi çerçevesi içerisinde değerlendirilen ya da analitik yöntem sayesinde yeniden yapılandırılmış unsurlarına odaklanmaktadır. Burada kastedilen, karşılaştırma faaliyetine konu edilen her bir hukuk sisteminin yapısal anlamda ele alınması değil; araştırma konusu hukuki sorunun, yapısal anlamda açıklığa kavuşturulmasıdır. Tarihsel yöntem ise, karşılaştırmalı hukuka ilişkin bahsi geçen tüm yöntemler açısından tamamlayıcı bir işleve sahiptir. Hukuk sistemleri arasında tespit edilen benzerlik ve farklılıkların, öteden beri süregelen kültürel bir geleneğe mi yoksa tamamen tarihsel rastlantılara mı dayandığını, bu yöntem sayesinde öğrenebiliriz. Hukukun kendi bağlamı içerisinde anlaşılmasını sağlayan yöntem ise, her ne kadar tarihsel yöntem ile büyük bir etkileşim içerisinde olsa da, temel itibariyle hukukun kültür, ekonomi, psikoloji vb. hukuk dışı disiplinlerle olan bağlamını sosyal anlamda incelemektedir. Hukukun kendi bağlamı içerisinde anlaşılmasını esas alan yöntem, bahsi geçen disiplinlerden elde edilen çözümlemeleri işlevsel ya da analitik yönteme kıyasla daha kapsamlı bir şekilde değerlendirmektedir ${ }^{101}$.

98 ibid 189.

99 Van Hoecke (n 17) 28.

100 ibid 28.

101 Söz konusu yöntemlere ilişkin genel bir değerlendirme için bkz. ibid 28 vd. 
Peki karşılaştırmalı hukuk araştırmalarında uygulanabilecek yöntemleri yukarıda bahsi geçen yöntemler ile sınırlı tutabilir miyiz? Söz konusu yöntemler açısından sınırlı sayı ilkesinin hâkim olduğu söylenemez. Ancak, gerçekleştirilecek araştırmanın konusu ve kapsamı doğrultusunda söz konusu yöntemlerden kimi zaman tek başına kimi zaman ise farklı yöntemlerin birleşimi doğrultusunda bir arada yararlanmak suretiyle gerçekleştirilecek karşılaştırmalı hukuk araştırmalarının, daha verimli sonuçlara ulaşılmasını sağlayabileceği söylenebilir. Bu kapsamda, karşılaştırmalı hukuk araştırmalarını ayrı bir bakış açısıyla yorumlayabilmek açısından hukuk iktibasına ilişkin gerçek deneyimlerden yararlanılabilip yararlanılamayacağ 1 sorusu aklımıza gelebilir. Hukuk iktibası, karşılaştırmalı hukuk araştırmaları bakımından bir amaç ya da sonuç olarak değerlendirilebilir; ne var ki hukuk iktibası deneyimi, özü itibariyle ayrı bir yöntem olarak değerlendirilmemelidir ${ }^{102}$. Zira bir hukuk sistemi bakımından başarılı kabul edilebilecek bir hukuk iktibası modeli, bir başka hukuk sistemi açısından başarılı olmayabilir. Örneğin Kara Avrupası hukuk sistemindeki aile hukukuna ilişkin düzenlemelerin, Afrika’daki sömürgecilik faaliyetleri sırasında pek çok Afrika ülkesi tarafından iktibas edilmesi, kültürel ve sosyal farklılıkların derinliği sebebiyle başarılı olmayan bir hukuk iktibası deneyimi olarak öğretide kabul edilmektedir ${ }^{103}$. Nitekim öğretide Van Hoecke'ye göre, karşılaştırmalı hukuk araştırmalarından yararlanmak isteyen ancak bunu belirli bir yöntem doğrultusunda gerçekleştiremeyecek toplumlar, uygulamada hukuk iktibasına daha çok başvurmaktadırlar ${ }^{104}$. Buna rağmen, uygulamada başarılı olan hukuk iktibası çalışmaları da vardır; fakat bu çalışmalarda, esas itibariyle hukukun kendi bağlamı içerisinde anlaşılmasını sağlayan yöntemden istifade edildiği anlaşılmaktadır ${ }^{105}$.

Zweigert/Kötz'ün, işlevsel denklik yönteminin karşılaş̧ırmalı hukuk çalışmalarında uygulanabilir olmasını sağlayan ve bu yöntemin adeta bir düşünce şekli olarak benimsenmesinde ve öğretiye tanıtılmasında büyük katkıları olan çalışmaları, konuya ilişkin yayınlanmış ilk eser olmasından ötürü büyük önem arz etmektedir ${ }^{106}$. Öğretide pek çok yazar tarafından yüceltilen ve karşılaştırmalı hukuk ile büyük ölçüde özdeşleştirilen söz konusu yöntem, aynı zamanda yoğun eleştirilere de maruz kalmıştır.

$\mathrm{Bu}$ doğrultudaki eleştirilerin ilk ayağını, işlevsel denklik yönteminin öğretide kabul edilen genel tanımındaki unsurlar oluşturmaktadır. İşlevsel denklik yöntemindeki temel anlayış, araştırma konusu hukuki soruna ilişkin çeşitli hukuk sistemlerinde muhtelif kural ya da kurumlar öngörülmüş olmasına ve söz konusu kural yahut kurumlar tarafından; ilgili hukuki sorunun farklı yollardan çözüme ulaştırılmasına rağmen, sunulan çözümün pratik açıdan benzer olduğuna ilişkin varsayıma

102 ibid 30.

103 Ayrıntılı bilgi için bkz. Mark Van Hoecke, 'Family Law Transfers from Europe to Africa: Lessons for the Methodology of Comparative Legal Research' in John Gillespie and Pip Nicholson (eds), Law and Development and the Global Discourses of Legal Transfers (2012) 273 vd. (Van Hoecke, Family).

104 Van Hoecke (n 17) 30.

105 ibid 30 .

$106 \mathrm{Ne}$ var ki öğretide Husa'ya göre; Zweigert/Kötz, Rabel tarafından geliştirilen işlevsellik yöntemine ilişkin metodolojik talimatları en yalın hâliyle takip etmekle yetinmiş ve söz konusu yöntemi, hukuk disiplinine uygularken önemli nitelikte bir katkı sağlamamışlardır. Bkz. Husa (n 20) 1108. 
dayanmaktadır ${ }^{107}$. Her ne kadar farklı toplumlara esas teşkil eden kültürel yapı, benzer sorunların benzer bir şekilde yapılandırılmasına olanak sağlayabileceği gibi, farklı bir şekilde yapılandırılmasına da olanak sağlayabilir. İşlevsel denklik yönteminin temelini oluşturan bu yaklaşım, karşılaştırılabilecek konuların daha sınırlı bir hâl almasına; etik değerler, siyasi ideolojiler, kültürel farklılıklar ve dini inanışların etkisi sonucunda, hukukun pek çok alanında söz konusu yöntemin uygulanamamasına yol açtığg için eleştirilmektedir ${ }^{108}$. Somutlaştırmak gerekirse, bu yaklaşım işlevsel bakımdan denklik yönteminin, Batı hukuku anlayışında gelişen hukuk sistemleri arasında daha verimli sonuçlara ulaşılmasının hedeflenmiş olduğu inancındadır. Zira hukuk kurallarının dini kurallar çerçevesinde geliştiği bir hukuk sistemi ile Batı hukukunu benimsemiş bir hukuk sistemi arasında gerçekleştirilmek istenen karşılaştırma faaliyetinin, işlevsel denklik yöntemi çerçevesinde gerçekleştirilebilmesinin pek mümkün olmadı̆̆ 1 kanaati hâkimdir ${ }^{109}$.

Eleştirilerin ikinci ayağını ise, işlevsel denklik yöntemi uygulayıcılarının; sadece hukuk kuralları ya da hukuki kurumlarla sınırlı bir yaklaşım doğrultusunda hukuki sorunları ele almaları ve bu doğrultuda ilgili hukuki sorunun yeteri kadar kendi bağlamında ele alınmadan değerlendiriliyor olması yönündedir ${ }^{110}$. Bu eleştiri, işlevsel denklik yönteminin; hukuk ve kültür arasındaki ilişkiyi kimi zaman göz $\operatorname{ard}_{1}$ edebildiği ${ }^{111}$ yönünde öğretide ileri sürülen diğer eleştirileri de kapsamaktadır. Nitekim karşılaştırmalı hukuk öğretisinde Legrand, hukukun kendi bağlamı içerisinde anlaşılması çabasının hukuk kural ya da kurumlarının anlaşılmasından daha önemli olduğu inancındadır ${ }^{112}$. Bu yaklaşım doğrultusunda, hukuki pozitivizmin sadece yürürlükte olan hukukun değerlendirilmesine olanak sağlayan statik bir değerlendirmeye imkân verdiğini ${ }^{113}$ ve bu durumun, karşılaştırmalı hukuk ile uğraşan bilim insanlarının düşünme biçimi açısından, bağlayıcı olarak nitelendirilebilecek kurallar ile kendilerini sınırlamalarına yol açacağı kanaatindedir ${ }^{114}$. Özü itibariyle hukukun ne olduğunu ve hangi hukukun uygulanacağını belirleyen hukuki pozitivizmden ${ }^{115}$, karşılaştırmalı hukuk çalışmalarında özellikle uzak durulması gerektiğinin vurgusunu yapan yazar, hukuk kuralını ya da hukuki kurumu tek başına değerlendiren aksi bir yaklaşımın, hukuk sisteminin yapısı hakkında oldukça yüzeysel nitelikte bilgi ihtiva ettiğini düşünmektedir ${ }^{116}$. Karşılaştırmalı hukuk açısından sorulması gereken doğru soruların yanıtlarının, hukuk kurallarında ya da hukuki kurumlarda aranmaması gerektiğini özellikle belirten Legrand, bu doğrultuda, “... bir hukuk kuralının anlamının,

107 Basedow (n 2) 889; Örücü, Eski ve Yeni (n 2) 84 vd.; Van Hoecke (n 17) 9.

108 Örücü, Eski ve Yeni (n 2) 87 vd.

109 Jaakko Husa, 'Functional Method in Comparative Law - Much Ado About Nothing?' (2013) 2(1) European Property Law Journal 4, 19 (Husa, Functional).

110 Aynı yönde bkz. Husa (n 20) 1110.

111 Husa, Functionalism (n 54) 446.

112 Pierre Legrand, 'The Impossibility of Legal Transplants' (1997) 4(2) Maastricht Journal of European and Comparative Law 111, 114 (Legrand, Transplants).

113 Pierre Legrand, 'The Verge of Foreign Law' (2010) 1 Romanian Journal of Comparative Law 73, 80.

114 ibid $76 \mathrm{vd}$.

115 Öğretide Legrand, hukuki pozitivizmi, sadece yürürlükte olan hukuk kurallarını, hukuk olarak nitelendirmesi nedeniyle eleştirmektedir. Bkz. ibid 76.

116 Pierre Legrand, 'European Legal Systems Are Not Converging' (1996) 45(1) The International and Comparative Law Quarterly 52, 56. (Legrand, Converging). 
hiçbir açıklama gerektirmeyecek kadar açık olmasının mümkün olmadığını ... Nitekim, söz konusu hukuk kuralının anlamının, kural yorumlayan kişinin tarihsel ve kültürel açıdan koșula bağlanmış epistemolojik varsayımlarına dayandığını" ileri sürmektedir ${ }^{117}$. Dolayısıyla Legrand, hukuk kuralını sadece yazılı bir metin olarak değerlendirmemekte, onu hukuk kültürünün bir parçası olarak da kabul etmektedir ${ }^{118}$. Benzer şekilde öğretide Husa'da, işlevsel denklik yönteminin, hukuk ve kültür arasındaki ilişkiyi yeterli derecede yansıtamadığı kanaatini taşımaktadır ${ }^{119}$.

İşlevsel denklik yönteminin, karşılaştırma faaliyetinin gerçekleştirildiği hukuk sisteminin genel yapısı hakkında yeterli bilgiye ulaşılmasına imkân tanımadan, ilgili hukuki soruna yönelik çıkarımlarda bulunduğu yönündeki eleştiri de yine bu kapsamda değerlendirilmelidir. Bu duruma ilişkin olarak öğretide Gerber, işlevsel denklik yöntemi çerçevesinde özdeş ya da benzer nitelikteki hukuki sorunlara farklı hukuk sistemlerinde üretilen çözümlerin karşılaştırmaya konu edildiğini; ne var ki, ilgili hukuk sistemlerinde uygulanacak hukuk kuralının tespiti hususunda yetkili ve görevli mahkemelerin nasıl belirlendiği dikkate alınmadığı gibi, söz konusu mahkemelerin karar verme sürecine etki eden hususların da yeterince önemsenmediğini belirtmektedir. Gerbere göre, karşılaştırma faaliyeti sırasında tüm bu hususların göz önünde bulundurulması, çalışmanın daha faydalı olması açısından kaçınılmazdır ${ }^{120}$.

Eleştirilerin üçüncü ayağını ise, öğretide adeta inhisari bir nitelik atfedilen işlevsel denklik yönteminin yaygın bir şekilde uygulanması oluşturmaktadır. Karşılaştırmalı hukuk öğretisinde, gerçekleştirilecek araştırmanın konusu ve araştırmada hedeflenen amaç doğrultusunda, hukuki soruna en uygun yöntemin seçilmesi gerekliliğinden yukarıda bahsedilmişti. Ne var ki, uygulamada araştırmacılar çalışmanın amacına uygun bir nitelik arz edip etmediğine bakılmaksızın, işlevsel denklik yönteminin tek başına uygulanmasının çoğu zaman yeterli olduğunu düşünmektedirler. Nitekim, işlevsel denklik yönteminin götürü bir anlayış doğrultusunda uygulandığı böylesi durumlarda, çoğu zaman uygulanan yöntem, gerçek anlamda işlevsel değildir ${ }^{121}$.

Ayrıca Michaels' in de belirttiği üzere, karşılaştırmalı hukuk araştırmalarında benimsenecek yönteme ilişkin öğretideki tartışmaların sebeplerinden bir diğeri de işlevsel denklik yönteminin karşılaştırmalı hukukta tutarlı bir metodolojik yaklaşım doğrultusunda ele alınmayıp, daha çok faydacı yaklaşım ${ }^{122}$ çerçevesinde değerlendiriliyor olmasından kaynaklanmaktadır ${ }^{123}$. Bu nedenle, işlevsel açıdan denklik yönteminin tercih edildiği durumlarda, söz konusu yöntemin metodolojik anlamda daha istikrarlı

117 Legrand, Transplants (n 112) 114.

118 ibid 116.

119 Husa, Functionalism (n 54) 446.

120 Gerber (n 39) $205 \mathrm{vd}$.

121 Öğretide Michaels'e göre, yedi farklı yaklaşım, işlevsel denklik yöntemi başlığı altında uygulanmaktadır. Söz konusu yaklaşımlara ilişkin detaylı bilgi için bkz. Michaels (n 32) $344 \mathrm{vd}$.

122 İşlevsellik yönteminin, karşılaştırmalı hukukta faydacı yaklaşım çerçevesinde ele alındığına ilişkin bilgi için bkz. Esin Örücü, 'Methodology of Comparative Law' in Jan M. Smits (ed), Elgar Encyclopedia of Comparative Law (2 $2^{\text {nd }}$ edn 2012) 562 (Örücü, Methodology).

123 Michaels (n 32) 362; Örücü, Eski ve Yeni (n 2) 85. 
bir yapıya kavuşturulması; karşılaştırmaya konu edilen hukuk sisteminin daha iyi anlaşılmasına ve yöntemin, yeknesak bir uygulamaya kavuşturulmasına da büyük katkı sağlayacaktır.

İşlevsel denklik yöntemine ilişkin öğretide öne çıkan eleştirilerde, yöntemin eksiklikleri ve aksayan yönleri genel itibariyle doğru bir biçimde tespit edilmesine rağmen, yöntemin geliştirilmesinin mümkün olmadığı kanaati hâkimdir. İşlevsel denklik yöntemini neden benimsemediklerini haklı ve makul gerekçelerle ortaya koyan yazarlar, sistematik bir başka yöntem önerisinde ise çoğu zaman bulunmamaktadırlar. Karşılaştırmalı hukuk araştırmaları ile ilgilenen bilim insanlarının, düzenli biçimde işlevsel denklik yönteminin noksanlıklarını vurgulamaları, yeni bir yöntemin geliştirilebilmesi için ihtiyaç duyulan eleştirel ortama katkı sağlamasına rağmen ${ }^{124}$, söz konusu yöntem ile rekabet edebilecek nitelikte sistematik bir model önerisi hâlen ortaya koyulamamıştır. Karşılaştırmalı hukukta araştırmacının ilgi alanı, kendi içinde yetiştiği hukuk sistemine kıyasla, başka bir coğrafyada yürürlükte olan, kendine özgü özellikler ihtiva eden bir başka hukuk üzerine olacaktır ${ }^{125}$. Bu nedenle de, söz konusu hukukun; tarihsel, sosyal, politik, demografik, epistemolojik nedenler ${ }^{126}$ çerçevesinde şekillendiği bilgisini her daim zihnimizde canlı tutarak, karşılaştırma faaliyetini titizlikle gerçekleştirmemiz gerektiğini vurgulayan Legrand da uygulanabilecek herhangi bir yöntem önerisinde bulunmamaktadır ${ }^{127}$. Aslında Legrand, karşılaştırmalı hukuk çalışmalarında hiçbir yöntemin yeteri kadar uygun ve yeterli olacağına da inanmamaktadır ${ }^{128}$. Bu durum, işlevsel bakımdan denklik yönteminin her türlü hukuki sorunun çözümünde tutarlı bir yaklaşım

124 Michaels (n 32) 363.

125 Uygulama açısından değerlendirildiğinde, gerek yargılama aşamasında iddiasını temellendirmeye çalışan avukatın gerekse de yargılama sonucunda vereceği kararı gerekçelendirmeye çalışan hâkimin, mevzuat düzenlemeleri ve konuya ilişkin daha önceden tesis edilmiş içtihatlar ile uyumlu bir davranış biçimi sergilemeyi tercih edeceği açıtır. Yargılama sonucunda korunması hedeflenen değerlerin, değişmezliği ve öngörülebilirliğinin esas alındığı bu süreçte, birbiri ile çelişen ve yargı sistemindeki mevcut ahengi bozan tutumlardan kaçılınılır. Bkz. Legrand (n 113) 77. Ne var ki, karşılaştırmalı hukuk üzerine çalışan bilim insanlarının ilgi alanı, kendi içinde yetiştikleri hukuk değil, başka bir coğrafyada yürürlükte olan hukuktur. Bu durumu, deney ve gözleme dayanan bilimsel veriler ile açıklamak gerekirse, karşılaştırma faaliyetini gerçekleştirebilmek için birden fazla uluslararası hukuka ihtiyaç vardır. Birden fazla hukukun var olduğu bir karşılaştırma faaliyetinde, bilim insanları karşılaştıkları farklılıkların ne kadar önemsiz olduğunu da düşünseler ya da çalışmalarının tutarlı bir şekilde devamını sağlayabilmek için söz konusu ayrılıkları görmezden de gelseler, her hukukun kendine özgü ve benzersiz olduğu gerçeği değişmeyecektir. Bkz. ibid 79.

126 Legrand, bu duruma ilişkin örnek olarak, Fransa'da 15 Mart 2004 tarihli 2004-228 numaralı laiklik ilkesinin nasıl uygulanacağını tanzim eden yasa çerçevesinde, Devlet okullarında dini değerler ile özdeşleştirilebilecek işaretlerin taşınmasının ve kıyafetlerin giyilmesinin yasaklandığı düzenlemeyi örnek göstermiştir. Tarihsel, sosyal, demografik ve epistemolojik açıdan Fransa'dan farklı bir yapı ihtiva eden Kanada'da ise Yüksek Mahkeme, 12 yaşındaki Sih inancına mensup bir öğrencinin kirpanını (Sihlerin dini ibadetleri sırasında kullandıkları ve her zaman üzerlerinde taşımaları gerektiğine inandıkları nesneye verilen isim) okul sınırları içerisinde de üzerinde bulundurabilmesini kabul etmiştir. Dolayısıyla verilen kararların, her hukuk sisteminin kendi özellikleri doğrultusunda ayrı ayrı değerlendirilmesi gerektiği anlaşılmaktadır. Legrand’a göre, verilen bu kararları hukuki pozitivizmin gereken duyarlılığı göstermeyen yaklaşımı açısından farklı coğrafyalarda değerlendirirsek, birbirinden oldukça ayrı sonuçlara da ulaşabiliriz. Örneğin Fransa'da verilen kararın, Amerika Birleşik Devletleri bakımından inanç özgürlüğüne aykırı bulunması kuvvetle muhtemeldir. Bkz. ibid 79 vd.

127 Husa (n 20) 1108 vd.

128 Legrand’ın söz konusu yaklaşımının eleştirisi için bkz. Hoecke, Deep (n 96) 172. Legrand’a göre önemli olan, hukuk kültürünün derinlemesine anlaşılmasına ilişkin çalışmalara ağırlık verilmesi gerekliliğidir. Karşılaştırmalı hukuk araştırmalarının, hukuk sistemlerini birleştirici etkisini kural olarak kabul etmeyen Legrand; çalışmalarını, heterojen bir yapı arz eden farklı hukuk kültürlerinden elde edilen bilginin meşru bir biçimde nasıl kullanılabileceği hususunda yoğunlaştırmaktadır. Bkz. Legrand, Transplants (n 112) 123. 
doğrultusunda çözüm üretilmesine olanak sağladığı anlamına da gelmemelidir ${ }^{129}$. Dolayısıyla, işlevsel denklik yöntemine seçenek oluşturabilecek diğer yöntemlerin her çalışmada ayrıca göz önünde bulundurulması gerekmektedir. Karşılaştırmalı hukuk açısından farklı bakış açılarının bir arada yer aldığı Örücü̉nün çalışması, hukuk araştırmalarında uygulanacak yöntem konusunda da öğretide önemli bir açılım sağlamaktadır. Nitekim Örücü’ye göre, her türlü çalışmada en doğru sonuca ulaşmamızı sağlayacak tek bir doğru yöntemin varlığından bahsedilemez ${ }^{130}$. Ne var ki, yöntemsel açıdan takip edilmesi gereken usul hakkında önemli bir referans olarak gösterilebilecek olan çalışmada izlenmesi gereken yöntem açısından verilen tavsiyeler, teorik anlamda çok değerli olmakla birlikte, pratik açıdan arzu edilen uygulanabilirliği ise sağlamamaktadır ${ }^{131}$.

Tüm bu yaklaşımlar sonucunda, karşılaştırmalı hukuk araştırmaları açısından en verimli sonuçlara, derinlemesine yapılan çalışmalarda rastlanıldığını söylenebilir. Peki bir hukuki soruna ilişkin olarak karşılaştırmalı hukuk araştırması derinlemesine nasıl yapılabilir? Karşılaştırma faaliyetinin gerçekleştirildiği hukuki soruna ilişkin, pozitivist bakış açısının ve betimsel bir anlayışın hâkim olmadığı tarihsel incelemeler, sosyolojik çalışmalar ve istifade edilmesinin gerekliliğine inanılan hukuk dışı diğer disiplinler, çalışmanın başlangıcında araştırmacıya kılavuzluk etmelidir. $\mathrm{Bu}$ durum, araştırmacının tek başına tüm çalışmayı tamamlaması yerine; farklı disiplinlerde uzman bilim insanlarının da katılımıyla araştırma gruplarının oluşturularak, karşılaştırmalı hukuk çalışmasının çok yönlü bir şekilde tamamlanabilmesine olanak sağlamaktadır. Nitekim konusunda yetkin bir tarihçinin, siyaset bilimcinin, sosyoloğun, dilbilimcinin, antropoloğun ve hatta deneyimli bir avukatın katılımıyla gerçekleştirilecek bir araştırma faaliyetinin ilgili konuyu farklı açlardan ve daha derinlemesine inceleyebileceği açıktır ${ }^{132}$. Elbette karşılaştırmalı bir hukuk araştırmacısı da çalışmasında ihtiyaç duyduğu hukuk dışı diğer disiplinlerden faydalanabilir. Ne var ki, karşılaştırmalı hukuk ile ilgilenen bütün araştırmacıların ilgili araştırma konusu çerçevesinde hukuk dışı diğer disiplinlerden her zaman gerektiği ölçüde yararlanabilecek bilgi birikimi ve deneyime sahip olduğu söylenemez ${ }^{133}$. Araştırmacının, çalışmasının başlangıç kısmı bakımından iyi bir yol haritası ile karşılaştırma faaliyetine başlaması kadar; karşılaştırma faaliyetinin devamı sırasında da ihtiyaç duyduğu ölçüde, hukuk dışı diğer disiplinlerde yetkin bilim insanlarından yardım talebinde bulunabileceğini bilmesi çok önemlidir. Hukuki araştırmanın konusu çerçevesinde öncelik verilmesi gerektiğine inanılan ve çalışmanın bağlamı doğrultusunda ele alınması gereken hukuk dişı disiplinlerden titizlikle istifade edildikten sonra, karşılaştırma faaliyetinin amacına en uygun olan yöntem ya da yöntemlerin araştırmacı tarafından belirlenmesi gerekmektedir. Bu aşamada, hukuk literatürü ve mahkeme kararları da araştırma ile olan ilgisine uygun olarak değerlendirilmelidir. Nitekim, karşılaştırmalı hukuk araştırmalarında her araştırma

129 Husa (n 20) 1111.

130 Örücü, Methodology (n 122) 573 vd.

131 Husa (n 20) 1113.

132 Bu yöndeki görüş için bkz. ibid 1116.

133 Bu yöndeki görüş için bkz. ibid 1116. 
konusuna özgü ayrı bir yöntemin belirlenmesi ${ }^{134}$, en elverişli yaklaşımı oluşturmaktadır ${ }^{135}$. Zira karşılaştırmalı hukuk araştırmalarındaki amaçların başkalığı, uygulanacak yöntem ya da yöntemlerin her araştırmada yeniden belirlenmesini gerektirmektedir. Gerekli değerlendirmeler yapılmaksızın, bir yöntemin diğerine kıyasla daha iyi sonuç vereceği götürü bir yaklaşım doğrultusunda kabul edilmemelidir. Yine bu aşamada gerekli görülmesi hâlinde, hukukun diğer kaynaklarından da istifade edilebilir. Son olarak, karşılaştırma sonucunda ulaşılacak çözümlemelerin, toplumda yerleşik değerler bakımından farklı bir bakış açısı ortaya koymasının imkân dahilinde olduğu durumlarda, örneğin aile hukukuna ilişkin kökten bir değişikliğe ihtiyaç gösteren yeni bir yasa teklifinde, konuya ilişkin meclis tutanaklarından ve basın-yayın organlarında yayınlanan görüşlerden de yararlanılması faydalı olacaktır ${ }^{136}$.

\section{KAYNAKÇA}

Antalya, O. Gökhan, Hukuk Metodolojisi, (Seçkin 2021).

Basedow, Jürgen, Comparative Law and Its Clients', (2014) 62 (4) The American Journal of Comparative Law 821-857. Bu makalenin Türkçe çevirisi için bkz. Jürgen Basedow, 'Karşılaştırmalı Hukuk ve Kullanıcıları' (Gökçe Kurtulan tr) (2016) LXXIV (2) İ̈̈HFM 879-917.

Fauvarque-Cosson Bénédicte, 'Development of Comparative Law in France' in Mathias Reimann ve Reinhard Zimmermann (eds), The Oxford Handbook of Comparative Law (Oxford University Press 2006) 39-69.

Donahue, Charles, 'Comparative Law Before the Code Napoléon' in Mathias Reimann ve Reinhard Zimmermann (eds), The Oxford Handbook of Comparative Law, (Oxford University Press 2006) 4-38.

Gerber, David J., 'Sculpting the Agenda of Comparative Law: Ernst Rabel and the Façade of Language' in A. Riles (ed), Rethinking the Masters of Comparative Law (2001) 190-208.

Graziadei, Michele, 'The Functionalist Heritage' in Pierre Legrand and Roderick Munday (eds), Comparative Legal Studies: Traditions and Transition (Cambridge University Press 2003) 100-127.

Husa, Jaakko, 'Methodology of Comparative Law Today: From Paradoxes to Flexibility?' (2006) 58 (4) In: Revue internationale de droit comparé, 1095-1117.

Husa, Jaakko, 'Farewell to Functionalism or Methodological Tolerance?' (2003) 67(3) Rabels Zeitschrift für ausländisches und internationales Privatrecht / The Rabel Journal of Comparative and International Private Law, 419-447 (Husa, Functionalism).

Husa, Jaakko, 'Functional Method in Comparative Law - Much Ado About Nothing?' (2013) 2(1) European Property Law Journal 4-21 (Husa, Functional).

Kurtulan Güner, Gökçe, Trust ve Türk Hukuku Açısından Değerlendirilmesi (On İki Levha 2020).

Kurtulan Güner, Gökçe, 'Türk Hukuku için Yeni (?) Bir Kurum: Teminat Yöneticisi' (İstanbul 2021) <https://law. khas.edu.tr/tr/turk-hukuku-icin-yeni-bir-kurum-teminat-yoneticisi> Erişim Tarihi: 10.08.2021.

134 İlgili toplumdaki hangi organın hukuk kurallarını yürürlüğe koyma yetkisi ile donatıldığından ya da hangi değerlerin hukukun gelişiminde etkili olduğundan bağımsız şekilde günümüzde yürürlükte olan hukuk sistemlerini değerlendirmek gerekirse; ilk olarak, muhtelif toplumların farklı hukuk sistemlerinin etkisi altında olduğu söylenebilir. Herkes tarafından kolaylıkla gerçekleştirilebilecek bu tespit dahi, başlı başına tek bir yöntemin gerçekleştirilmek istenen karşılaştırmalı hukuk çalışmalarında yeterli olmayacağının önemli bir göstergesidir. Bkz. Husa, Functional (n 109) 20 vd.

135 Benzer yönde bir yaklaşım için bkz. Vernon, Valentine Palmer, 'From Lerotholi to Lando: Some Examples of Comparative Law Methodology' (2005) 53(1) The American Journal of Comparative Law 261, 266 ve 290.

136 Karşılaştırmalı bir hukuk araştırmasının derinlemesine yapılabilmesi için takip edilmesi gereken süreç, öğretide Van Hoecke tarafından detaylıca ele alınmıştır. Bkz. Van Hoecke, Deep (n 96) 191 vd. 
Legrand, Pierre, 'European Legal Systems Are Not Converging' (1996) 45(1) The International and Comparative Law Quarterly 52-81 (Legrand, Converging).

Legrand, Pierre, 'The Impossibility of Legal Transplants' (1997) 4(2) Maastricht Journal of European and Comparative Law 111-124 (Legrand, Transplants).

Legrand, Pierre, 'The Verge of Foreign Law' (2010) 1 Romanian Journal of Comparative Law 73-104.

Michaels, Ralf, 'The Functional Method of Comparative Law' in Mathias Reimann ve Reinhard Zimmermann (eds), The Oxford Handbook of Comparative Law, (Oxford University Press 2006) 340-382.

Michaels, Ralf, 'Two Paradigms of Jurisdiction', (2007) 27 Michigan Journal of International Law 1003-1069 (Michaels, Paradigms).

Oğuz, Arzu, 'Hukukun Bağımsız Bir Alanı Olarak Karşılaştırmalı Hukukun Konusu ve Metodu', (2002) 22 (2) Milletlerarası Hukuk ve Milletlerarası Özel Hukuk Bülteni 451-508.

Örücü, Esin, The Enigma of Comparative Law (Springer 2004)

Örücü, Esin, 'Karşılaştırmalı Hukukçu Gözüyle İskoç Hukuk Sistemi' (1990) 18 İstanbul Üniversitesi Mukayeseli Hukuk Araştırmaları Dergisi, 71-81. (Örücü, Karşılaştırmalı).

Örücü, Esin, 'Law As Transposition' (2002) 51(2) The International and Comparative Law Quarterly 205-223 (Örücü, Transposition).

Örücü, Esin, 'Karşılaştırmalı Hukukta Eski ve Yeni' (Nurcan Yılmaz Özel tr, İdare Hukuku ve İlimleri Dergisi, 18 (1) 2019) 79-111 (Örücü, Eski ve Yeni).

Örücü, Esin, 'Methodology of Comparative Law' in Jan M. Smits (ed), Elgar Encyclopedia of Comparative Law ( $2^{\text {nd }}$ edn 2012) 560-576 (Örücü, Methodology).

Özsunay, Ergun, 'Karşılaştırmalı Hukukun Çeşitli Görünümleri', (1976) 10 (13) İstanbul Üniversitesi Mukayeseli Hukuk Araştırmaları Dergisi 3-13.

Serozan, Rona, 'Hukukta Yöntem' (2013) 8 Yaşar Üniversitesi E-Dergisi (Prof. Dr. Aydın Zevkliler’e Armağanı) 2423-2440.

Sacco, Rodolfo, 'Legal Formants: A Dynamic Approach to Comparative Law' (1991) American Journal of Comparative Law (part II) 343-401.

Samuel, Geoffrey, An Introduction to Comparative Law Theory and Method (Oxford University Press 2014).

Van Hoecke, Mark, 'Methodology of Comparative Legal Research' (2015) Law and Method 1-35.

Van Hoecke, Mark, 'Deep Level Comparative Law' in Mark Van Hoecke (ed), Epistemology and Methodology of Comparative Law (2004) 165-195 (Van Hoecke, Deep).

Van Hoecke, Mark, 'Family Law Transfers from Europe to Africa: Lessons for the Methodology of Comparative Legal Research' in John Gillespie and Pip Nicholson (eds), Law and Development and the Global Discourses of Legal Transfers (2012) 273-295 (Van Hoecke, Family).

Valentine Palmer, Vernon, 'From Lerotholi to Lando: Some Examples of Comparative Law Methodology' (2005) 53(1) The American Journal of Comparative Law 261-290.

Reinhard Zimmermann, 'Codification: "The Civilian Experience Reconsidered on the Eve of a Common European Sales Law' (2012) 8 (4) European Review of Private Law 367-399. Bu makalenin Türkçe çevirisi için bkz. Reinhard Zimmermann, 'Kodifikasyon: Avrupa Ortak Satım Hukuku Arifesinde Kıta Avrupası Deneyimlerinin Değerlendirilmesi' (Ece Baş Süzel ve Meliha Sermin Paksoy trs) (2015) LXXIII (2) İ̈̈HFM 409-436.

Zweigert, Konrad and Kötz, Hein, An Introduction to Comparative Law (Tony Weir tr, 3rd edn, Oxford University Press 1998). 